\title{
ATIVIDADE DE UREASES E CONCENTRAÇÃO DE AMINOÁCIDOS EM TABACO INOCULADO COM FUNGOS MICORRÍZICOS ARBUSCULARES
}

\section{DANIELE TAKAHASHI}

Engenheira Agrônoma

Orientador: Prof. Dr. MARCIO RODRIGUES LAMBAIS

Dissertação apresentada à Escola Superior de Agricultura "Luiz de Queiroz", Universidade de São Paulo, para a obtenção do título de Mestre em Agronomia, Área de Concentração: Solos e Nutrição de Plantas.

PIRACICAB A

Estado de São Paulo - Brasil

Maio - 2001 


\section{ERRATA}

Na página $\mathrm{v}$, linha 3, onde lê-se "induzido em", ler "induzido por".

Na página vi, linha 13, onde lê-se "Em substrato", ler "Em plantas crescendo em substrato".

Na página vi, linha 16, onde lê-se "tabaco foi", ler "tabaco, em todos os tratamentos, foi".

Na página vii, linha 16, onde lê-se "experimental conditions", ler "treatment".

Na página 2, linha 14, onde lê-se "expressão de proteínas", ler "expressão de genes codificando proteínas".

Na página 19 , linha 5 , onde lê-se " $2500 \mathrm{rpm}$ ", ler " $3795 g$ ".

Na página vi, linha 13, onde lê-se "overnight", ler "a noite toda".

Na página 45, linha 23, onde lê-se "New Phytologist, n.121, p.227-234, 1992.", ler "New Phytologist, v.121, n.2, p.227-234, 1992".

Na página 46, linha 9, onde lê-se "Molecular Plant-Microbe Interections, v.8, n.2, p. 252-258, 1995.", ler "Molecular Plant Microbe Interactions, v.8, n.2, p.252-258, 1995.

$\mathrm{Na}$ página 47, linha 23, onde lê-se "Ammonia assimilation in Zea mays $\mathrm{L}$. infected with a vesiculararbuscular mycorrhizal fungus Glomus fasciculatum.", ler " Ammonia assimilation in Zea mays L. infected with a vesicular-arbuscular mycorrhizal fungus Glomus fasciculatum."

Na página 49, linha 5, onde lê-se "Glomus fasciculatum, v.138, n.3, p.411-417, 1998.", ler " Glomus fasciculatum. New Phytologist, v.138, n.3, p.411-417, 1998."

Na página 51, linha 13, onde lê-se "KHALIQ, A. Effect of inoculation with vesicular-arbuscular mycorrhizal fungus (Glomus mosseae) and application of phosphorus on dry matter and phosphorus uptake of maize (Zea mays L.). Journal-of-Animal-and-Plant-Sciences (Pakistan), v.7, n.1-2, p. 45-48, 1997.", ler " KHALIQ,

A. Effect of inoculation with vesicular-arbuscular mycorrhizal fungus (Glomus mosseae) and application of phosphorus on dry matter and phosphorus uptake of maize (Zea mays L.). Journal of Animal and Plant Sciences, v.7, n.1-2, p. 45-48, 1997.

Na página 51, linha 19, onde lê-se "Journal-of-Plant Nutrition (USA)," ler "Journal of PLant Nutrition". Na página 51, linha 28, onde lê-se "Molecular Plant-Microbe Interactions," ler "Molecular Plant Microbe Interactions,".

Na página 52, linha 2, onde lê-se "Avanos", ler "Avanços".

Na página 53, linha 4, onde lê-se "Microbial Reviews", ler "Microbiological Reviews".

Na página 53, linha 14, onde lê-se "Avanos", ler "Avanços".

Na página 54, linha 20, onde lê-se "Phytopatológica", ler "Phytopatologica".

Na página 55, linha 25, onde lê-se "Trends in Ecology and Evolution", ler "Trends in Ecology and Evolution". 
Dados Internacionais de Catalogação na Publicação (CIP)

DIVISĀO DE BIBLIOTECA E DOCUMENTAÇĀO - Campus "Luiz de Queiroz"/USP

\section{Takahashi, Daniele}

Atividade de ureases e concentração de aminoácidos em tabaco inoculo com fungos micornizicos arbusculares / Daniele Takahashi. - - Piracicaba, 2001.

$57 \mathrm{p}$.

Dissertação (mestrado) - - Escola Superior de Agricultura Luiz de Queiroz, 2001. Bibliografia.

1. Aminoacido 2. Dosagem 3. Fumo 4. Micoriza 5. Nicotiana 6. Nitrogênio I. Titulo

$\operatorname{CDD} 633.71$

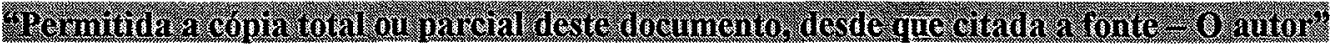


Não sois máquina, homem é o que sois.

(Charles Chaplin) 


\section{AGRADECIMENTOS}

A Deus, por tudo.

À FAPESP, pela bolsa concedida.

Ao Prof. Dr. Marcio Rodrigues Lambais, pela orientação e constante otimismo.

Ao Prof. Dr. Carlos Alberto Labate, ao técnico José e ao aluno Juliano pela ajuda na extração e análise dos aminoácidos.

Aos técnicos Denise e Fernando pelo auxílio na condução do experimento e pela amizade.

Aos amigos do Laboratório de Microbiologia do Solo, Robinson, Angela, Tais, Denise, Leandra, Adrianinha, Adriana, Beth, Beatriz, Simão, Juliano, Vinícius e Iara pelas trocas de experiências e amizade.

Aos amigos: Carlos (Jabá), Cristiano, João de Deus, Mírian, Simone (Bactéria), Márcia (Fanni) e Janaína Rodrigues.

Á minha querida família, meus pais Mitsuru e Angela, meus irmãos Henry e Felipe e minha avó Ina por me apoiarem mesmo sem entender porque tenho estudado tanto.

Ao Denis, é claro. 


\section{SUMÁRIO}

Página

RESUMO $\mathrm{V}$

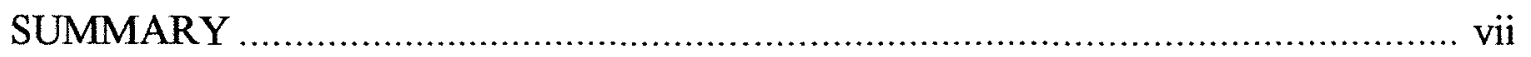

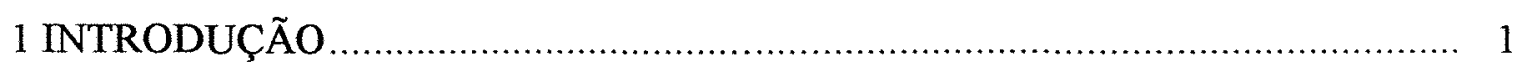

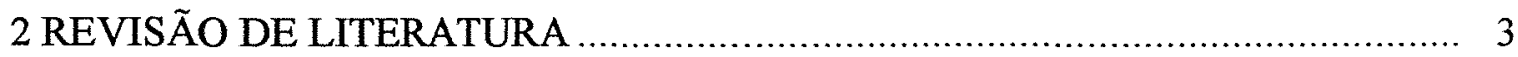

2.1 Micorrizas arbusculares: aspectos gerais .............................................. 3

2.2 Desenvolvimento de MAs ................................................................. 4

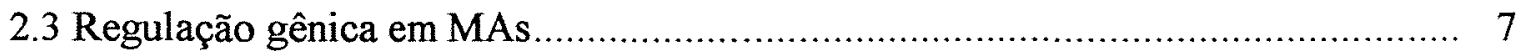

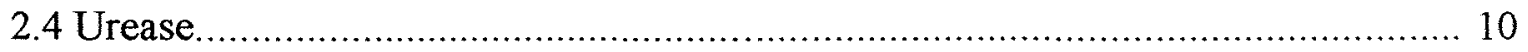

2.5 Metabolismo de nitrogênio em plantas micorrizadas ................................... 13

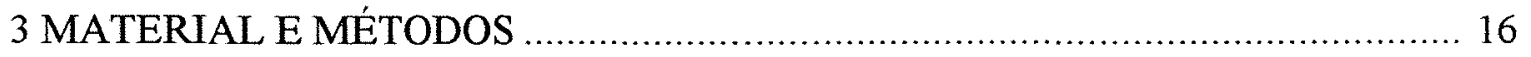

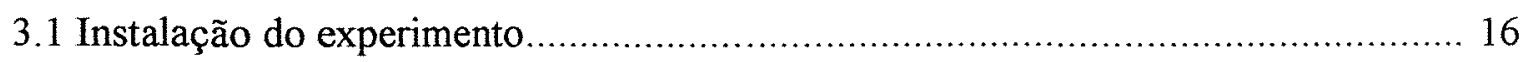

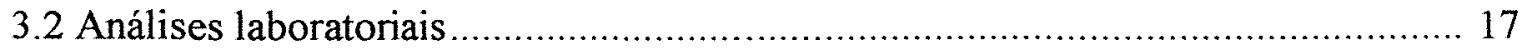

3.2.1 Determinação da massa da matéria seca da parte aérea e do sistema radicular ... 17

3.2.2 Avaliação da colonização micorrízica ............................................ 17

3.2.3 Extração e quantificação de proteínas ............................................... 17

3.2.4 Determinação das atividades de ureases ......................................... 18

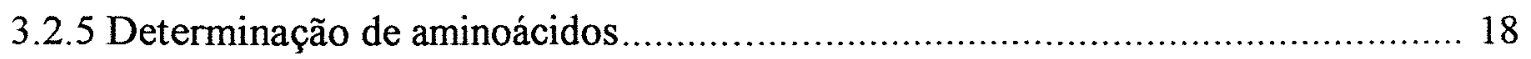

3.2.6 Determinação de nutrientes na parte aérea.......................................... 19

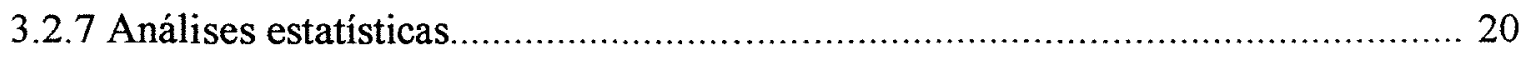

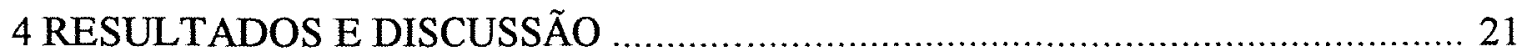

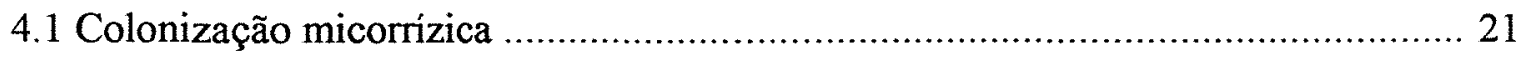

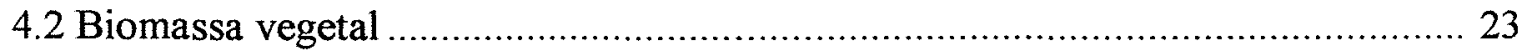

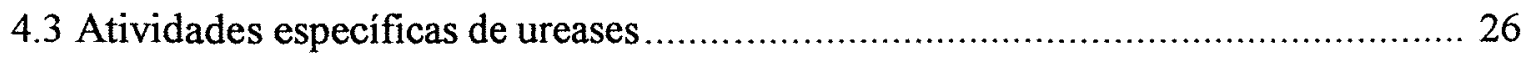

4.4 Concentrção de proteinas em extratos de raízes ........................................... 29

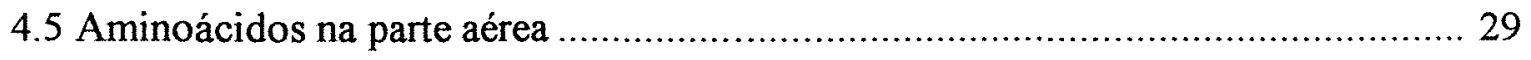

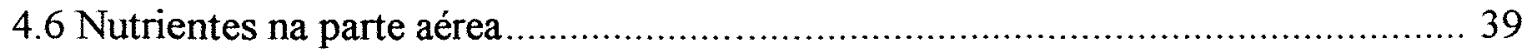

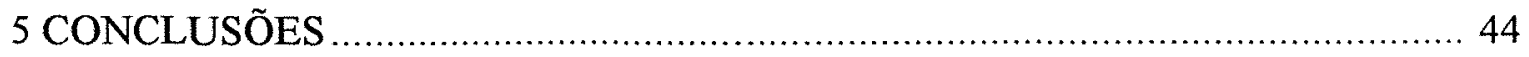

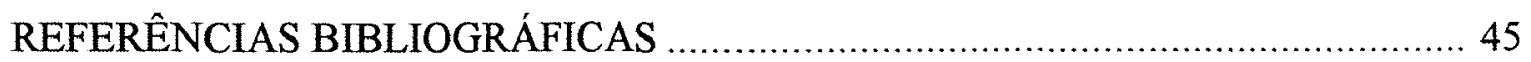




\section{ATIVIDADES DE UREASES E CONCENTRAÇÃO DE AMINOÁCIDOS EM TABACO INOCULADO COM FUNGOS MICORRÍZICOS ARBUSCULARES}

Autora: DANIELE TAKAHASHI Orientador: Prof. Dr. MARCIO RODRIGUES LAMBAIS

\section{RESUMO}

O papel das micorrizas arbusculares (MAs) no metabolismo de nitrogênio nos vegetais é pouco conhecido. Pouco se sabe também sobre os mecanismos que regulam a absorção, assimilação de nitrogênio em MAs. Recentemente, um gene altamente induzido em raizes de tabaco micorrizadas foi clonado e caracterizado. Esse gene codifica uma proteína acessória da urease (UreG). Sua regulação diferencial em MAs sugere que fungos micorrízicos arbusculares podem induzir alterações no metabolismo de nitrogênio nos vegetais, e/ou que ureases podem ser importantes no controle do desenvolvimento da simbiose. O objetivo deste trabalho foi verificar se ocorrem ou não alterações nas atividades de ureases em raízes de tabaco micorrizadas, e se essas alterações estão relacionadas com alterações do perfil de aminoácidos solúveis e com o crescimento fingico intrarradicular. Para isso, plântulas de tabaco foram inoculadas com Glomus clarum ou Glomus intraradices, e cultivadas em substrato esterilizado contendo 50,100 ou $150 \mathrm{mg} \mathrm{kg}^{-1}$ de Nitrogênio, na forma de uréia ou sulfato de amônio. Oito semanas após a inoculação, foram avaliados: matéria seca da parte aérea e sistema radicular, colonização micorrízica intraradicular, atividades de ureases nas raízes, e concentração e perfil de aminoácidos solúveis na parte aérea. A colonização 
intraradicular por G. clarum teve aumento induzido pelo aumento das doses de nitrogênio. As atividades de ureases de plantas não-inoculadas aumentaram com o aumento da dose de $\mathrm{N}$-uréia aplicada ao substrato. Quando cultivadas com $50 \mathrm{mg} \mathrm{kg}^{-1}$ de $\mathrm{N}$-sulfato de amônio, as raizes de plantas inoculadas com G. clarum apresentaram atividades de ureases mais elevadas do que nos controles não-inoculados. Já, as raízes de plantas inoculadas com $G$. intraradices apresentaram maiores atividades de ureases, em relação aos controles não-inoculados, quando cultivadas com $100 \mathrm{mg} \mathrm{kg}^{-1} \mathrm{de} \mathrm{N}$-sulfato de amônio. Com $150 \mathrm{mg} \mathrm{kg}^{-1} \mathrm{~N}$-uréia, as atividades de ureases foram 3 vezes menores nas raizes micorrizadas do que nas não-micorrizadas. As atividades de ureases apresentaram correlação positiva e significativa com a colonização intrarradicular nos tratamentos com $\mathrm{N}$-sulfato de amônio. A inoculção de plântulas com $G$. intraradices ou G. clarum resultou em diminuição da concentração de aminoácidos livres, em substrato com $50 \mathrm{mg} \mathrm{kg}^{-1} \mathrm{~N}$-sulfato de amônio, em relação aos controles não inoculados. Em substrato $150 \mathrm{mg} \mathrm{kg}^{-1} \mathrm{~N}$-uréia a concentração de aminoácidos solúveis aumentou aproximadamente 10 vezes, em relação aos controles não-inoculados. $\mathrm{O}$ aminoácido encontrado em maior quantidade na parte aérea de tabaco foi a glutamina. Alterações nos perfis de aminoácidos na parte aérâ de plantas micorrizadas, em relação aos controles não micorrizados, foram observadas. Correlação significativa entre atividades de ureases nas raizes e concentração de aminoácidos solúeis na parte aérea não foi obsrervada. Os dados obtidos neste trabalho sugerem que as atividades de ureases nas raízes, em condições de baixo $\mathrm{N}$, podem estar relacionadas com a capacidadde de colonização intrarradicular dos fungos, e que fungos micorrizicos arbusculares podem alterar o metabolismo de $\mathrm{N}$ nas plantas. 


\title{
ATIVIDADES DE UREASES E CONCENTRAÇÃO DE AMINOÁCIDOS EM TABACO INOCULADO COM FUNGOS MICORRÍZICOS ARBUSCULARES
}

\author{
Author: DANIELE TAKAHASHI \\ Adviser: Prof. Dr. MARCIO RODRIGUES LAMBAIS
}

\begin{abstract}
\end{abstract}
The role of arbuscular mycorrhizae (AM) in the nitrogen $(N)$ metabolism of host plants is not understood, and the mechanisms regulating $\mathrm{N}$ uptake and assimilation in AM are not known. Recently, a gene highly induced in mycorrhizal tobacco roots was cloned and characterized. Its deduced amino acid sequence showed a high degree of homology to urease accessory proteins (UreG). The differential regulation of ure $G$ in AM suggests that arbuscular mycorrhizal fungi may alter $\mathrm{N}$ metabolism in the host plants, and/or that ureases may be important in controlling symbiosis development. The aim of this work was to determine whether urease activities are altered in mycorrhizal roots, and whether these alterations are related to changes in the relative abundance of free amino acids in shoots, and/or intraradical fungal growth. Tobacco seedlings were inoculated with Glomus clarum or Glomus intraradices, and grown in sterilized substrate containing 50, 100 or $150 \mathrm{mg} \mathrm{N} \mathrm{kg}^{-1}$, as urea or ammonium sulphate. Eight weeks after inoculation, the following parameters were evaluated: shoot and root dry weight, intraradical fungal growth, urease activities in roots, and free amino acid concentration in shoots. Intraradical colonization by $G$. clarum was higher than by $G$. intraradices, at the different experimental conditions. Root colonization by $G$. clarum and $G$. intraradices 
was induced in substrate with 50 and $100 \mathrm{mg} \mathrm{N}$-urea $\mathrm{kg}^{-1}$. Urease activities in nonmycorrhizal roots were higher at the highest $\mathrm{N}$-urea concentration. When grown in 50 mg N-urea $\mathrm{kg}^{-1}$, urease activities in roots colonized by G. clarum were higher than in non-mycorrhizal controls. In contrast, roots colonized by $G$. intraradices showed higher urease activities than non-mycorrhizal controls when grown in $100 \mathrm{mg} \mathrm{N}$-ammonium sulphate $\mathrm{kg}^{-1}$. Urease activities in mycorrhizal roots grown in substrate containing 150 $\mathrm{mg} \mathrm{N}$-urea $\mathrm{kg}^{-1}$ were 3-fold lower than in non-mycorrhizal controls. A significant positive correlation between urease activities and intraradical fungal growth was observed in roots grown with $\mathrm{N}$-ammonium sulphate. Inoculation of tobacco seedlings with G. intraradices or G. clarum resulted in decreased free amino acid concentration in the shoots, when grown with $50 \mathrm{mg} \mathrm{N}$-ammonium sulphate $\mathrm{kg}^{-1}$, as compared to the notinoculated controls. In mycorrhizal roots grown in substrate with $150 \mathrm{mg} \mathrm{N}$-urea $\mathrm{kg}^{-1}$, free amino acid concentration was approximately 10-fold higher than in nonmycorrhizal controls. Glutamine was the most abundant amino acid in tobacco shoots. Changes in the relative abundance of free amino acids in the shoots of mycorrhizal plants, as compared to non-mycorrhizal controls, were observed. The data suggest that urease activities in roots, at low $\mathrm{N}$ concentration, might be involved in the control of intraradical fungal growth, and that arbuscular mycorrhizal fungi may induce changes in the amino acid metabolism in tobacco. 


\section{INTRODUÇÃo}

Micorrizas arbusculares (MAs) são associações mutualísticas entre as raízes de plantas vasculares e fungos específicos, com perfeita integração fisiológica e funcional entre os simbiontes. Trata-se de uma simbiose praticamente universal, não só pelo grande número de plantas suscetíveis à micorrização, como também por sua ocorrência generalizada na maioria dos habitats naturais.

A ocorrência de MAs tem sido observada em mais de $80 \%$ das plantas terrestres, nos mais variados ambientes. A ubiquidade das MAs é, provavelmente, resultado da ausência de especificidade entre os simbiontes e de sua co-evolução.

$O$ resultado desta associação reflete-se, geralmente, no aumento da aquisição de nutrientes por ambos os simbiontes. A planta é favorecida, principalmente, pelo aumento na absorção de fósforo, enquanto o fungo beneficia-se dos carboidratos sintetizados pela planta.

As MAs têm importância fundamental no equilíbrio e na ciclagem de nutrientes do solo. Em sistemas agrícolas tropicais podem ser uma alternativa viável para o desenvolvimento de sistemas agrícolas sustentáveis e de baixo custo. Esta importância deve-se ao fato do fósforo ser um dos elementos mais limitantes para a produção vegetal em solos tropicais, além de ter baixa mobilidade na solução do solo. A adubação fosfatada é uma prática agrícola onerosa e as reservas naturais de fosfato utilizadas na fabricação de fertilizantes constituem-se em um recurso não-renovável.

Normalmente, as raízes colonizadas pelos fungos micorrizicos arbusculares (FMAs) não podem ser distinguidas das não-colonizadas pela simples observação macroscópica, pois não ocorrem alterações morfológicas visíveis. No entanto, profundas 
alterações fisiológicas e bioquímicas são detectadas tanto no fungo quanto no hospedeiro.

Os estudos de fisiologia, bioquímica e biologia molecular de MAs têm avançado significativamente nos últimos anos, em função do desenvolvimento de novas técnicas de deteç̧ão e manipulação de macromoléculas. No entanto, esses avanços são ainda muito pequenos quando comparados àqueles obtidos no estudo das interações planta-patógenos e leguminosas-(Brady)Rhizobium. As dificuldades encontradas no estudo da biologia molecular de MAs se devem principalmente à impossibilidade de cultivar os FMAs ou a micorriza in vitro.

Recentemente, diversos genes com expressão diferencial em MAs têm sido clonados e identificados. Dentre esses genes, um gene codificando uma proteína acessória da enzima urease (ureG), induzido em raízes de tabaco colonizadas por Glomus intraradices, pode ter papel importante no controle do desenvolvimento e ou eficiência das MAs. Normalmente, aumentos da expressão de proteínas acessórias da urease podem estar relacionados com aumentos das atividades de urease. Se atividades de ureases apresentam expressão diferencial em MAs não se sabe.

O objetivo deste trabalho foi verificar se ocorrem ou não alterações na atividade de urease em raízes de tabaco micorrizadas na presença de sulfato de amônio ou uréia, e se essa alteração está relacionada com o perfil de aminoácidos solúveis. 


\section{REVISÃO DE LITERATURA}

\subsection{Micorrizas arbusculares: aspectos gerais}

A capacidade das raízes de plantas estabelecerem relações compatíveis com certos fungos do solo é um fenômeno generalizado na natureza. Essas realações são conhecidas como micorrizas (Silveira, 1992). Mais de 6.000 espécies de fungos do solo são capazes de formar micorrizas com 240.000 espécies de plantas (Bonfante \& Perotto, 1995).

Com base nas características morfológicas e anatômicas, os diferentes tipos de micorrizas podem ser agrupados em três grandes grupos: ectomicorrizas, endomicorrizas e ectendomicorrizas. As endomicorrizas compreendem as ericóides, as orquidóides e as arbusculares (Silveira, 1992). Este trabalho têm como enfoque principal o estudo das interações endomicorrízicas arbusculares.

As micorrizas arbusculares (MAs) formadas entre as raízes da maioria das plantas vasculares e fungos da ordem Glomales (Zigomicetos) são as associações simbióticas mais abundantes na natureza (Blilou et al., 2000; Harrisson, 1999). Os fungos micorrízicos arbusculares (FMAs) são reconhecidos como simbiontes obrigatórios de mais de $80 \%$ das plantas terrestres, na maioria dos ecossistemas (Ginzberg et al., 1998). A presença generalizada das MAs nos mais diferentes ambientes é, provavelmente, resultado da ausência de especificidade e de co-evolução dos simbiontes (Cardoso \& Lambais, 1992). Nas MAs, as raizes das plantas superiores são invadidas pelas hifas dos FMAs, os quais colonizam intercelularmente o tecido cortical e diferenciam-se intracelularmente em estrutura típicas chamadas arbúsculos (BonfanteFasolo, 1984). 
As raízes colonizadas por FMAs (micorrizadas) não podem ser distinguidas das não-micorrizadas pela simples observação macroscópica, já que alterações morfológicas visíveis nas raízes não podem ser detectadas (Silveira, 1992). Apesar de não ocorrerem alterações morfológicas, a formação das MAs é acompanhada por consideráveis mudanças no metabolismo em ambos os simbiontes (Ginzber et al., 1998). A penetração do fungo e seu estabelecimento nas raízes do hospedeiro envolve uma seqüência complexa de eventos, os quais resultam na diferenciação dos arbúsculos (Bonfante-Fasolo \& Perotto, 1992). Os arbúsculos são envoltos por uma membrana plasmática vegetal diferenciada, e têm papel fundamental na transferência bi-direcional de nutrientes entre os simbiontes (Bonfante \& Perotto, 1995).

As MAs têm papel ecológico relevante, pois, a principal vantagem das plantas micorrizadas em relação às plantas não-micorrizadas é o aumento da absorção de diversos nutrientes, principalmente de nutrientes com baixa mobilidade na solução do solo, como P, Zn e Cu (Ezeta \& Santos, 1980; Silveira, 1992). Outras vantagens são: diminuição da toxidez por metais pesados (Nogueira, 1996; Siqueira et al., 1999) e maior resistência a doenças (Bodker et al., 1998). Normalmente, a formação de MAs também resulta em aumentos da biomassa vegetal (Khaliq \& Sanders, 1997; Khaliq et al., 1997).

\subsection{Desenvolvimento de MAs}

O processo de pré-infeç̧ão têm início com a germinação dos esporos no solo. A germinação de esporos de fungos micorrizicos e o crescimento inicial do tubo germinativo podem ocorrer na ausência das raízes, contudo, exsudatos radiculares e compostos voláteis com o $\mathrm{CO}_{2}$ podem estimular estes processos (Bécard et al., 1992). Altas concentrações de $\mathrm{CO}_{2}$ na rizosfera podem induzir a germinação dos esporos e crescimento do tubo germinativo (Sanders et al., 1998). Têm sido observado também que elevadas concentrações de $\mathrm{CO}_{2}$ podem induzir o crescimento dos FMAs nativos em gramíneas (Monz et al., 1994; Sanders et al., 1996). O aumento da concentração de $\mathrm{CO}_{2}$ 
induziu em 5 vezes no comprimento da hifa externa dos FMAs, em comparação com a concentração ambiente de $\mathrm{CO}_{2}$ (Sanders et al., 1998).

Compostos fenólicos específicos presentes nos exsudados radiculares podem estimular ou inibir o crescimento de algumas espécies de fungos micorrízicos (Douds et al., 1996). Partindo-se do princípio que os flavonóides são ativos em concentrações muito baixas, assume-se que eles não possuem efeito nutricional, e, assim, poderiam atuar como sinais moleculares para controlar o crescimento de fungos micorrízicos arbusculares na rizosfera (Harrison, 1999). Embora os compostos derivados de flavonóides possam influenciar os estágios iniciais do ciclo de vida do fungo, experimentos com mutantes de milho deficientes na produção de flavonóides indicou que eles não são essenciais para o desenvolvimento da simbiose (Bécard et al., 1995).

O desenvolvimento da simbiose é iniciado quando a hifa fúngica, originária de um propágulo, entra em contato com a raiz da planta hospedeira e diferencia-se em apressório. Embora os exsudados radiculares sejam capazes de estimular o crescimento da hifa e sua ramificação, eles não são capazes de estimular a formação do apressório (Giovannetti et al., 1993). Recentemente foi demonstrado que Gigaspora margarita pode formar apressório in vitro sobre a parede de células da epiderme isoladas de raízes de cenoura (planta hospedeira), mas não sobre paredes isoladas de células da epiderme de raízes de beterraba açucareira (planta não-hospedeira) (Nagahashi \& Douds, 1997). O fungo também reconheceu o tipo de células formando apressório sobre a parede de células corticais ou vasculares. Estes experimentos sugerem que o sinal para a formação do apressório encontra-se na parede de células da epiderme, hipótese anteriormente apresentada por Tester et al. (1987).

A formação do apressório é seguida pelo desenvolvimento da hifa de penetração e pela penetração propriamente dita. Apressórios desenvolvidos sobre fragmentos de parede celular de células da epiderme não foram capazes de formar hifa de penetração e não penetram a parede celular (Nagahashi \& Douds, 1997). Uma grande quantidade de mutantes vegetais nos quais os FMAs formam apressórios mas não formam hifa de penetração indicam que essa etapa da associação é controlada pela planta. Mutantes bloqueando este estágio de diferenciação dos fungos têm sido descritos 
em Pisum sativum e Vicia faba (Duc et al., 1989), Medicago sativa (Bradbury et al., 1991) e Phaseolus vulgaris (Shirtliffe \& Vessey, 1996). A penetração pode ocorrer por diferentes vias; em algumas espécies a hifa entra forçando a sua passagem entre duas células epidérmicas; em outros casos, a hifa penetra pela parede da célula do pêlo radicular ou da epiderme e cresce através da célula (Bonfante-Fasolo, 1984). Os mecanismos exatos envolvidos na penetração são desconhecidos; contudo, por analogia com vários patógenos biotróficos, têm sido sugerido que a produção localizada e específica de enzimas que degradam a parede celular pode facilitar a entrada da hifa sem induzir respostas de defesa (Bonfante-Fasolo \& Perotto, 1995). Os FMAs produzem, em quantidades relativamente reduzidas, exo-e endoglucanases, celulases, xiloglucanases e enzimas pectolíticas, incluindo poligalacturonase (Garcia-Garrido et al., 1992a; GarciaGarrido et al., 1992b).

A colonização intraradicular inicia-se pelo crescimento intercelular da hifa. Quando atinge o córtex, as ramificações formadas pela hifa intercelular penetram as paredes das células corticais e diferenciam-se em estruturas ramificadas conhecidas como arbúsculos. Embora um arbúsculo desenvolva-se dentro da célula, ele mantém-se no apoplasto, já que a membrana plasmática vegetal envolve-o completamente. A parede celular das hifas dos arbúsculos é menos espessa e menos organizada do que em hifas intercelulares, o que favorece um contato estreito entre os simbiontes. Nesse estágio, os simbiontes são separados apenas por suas membranas e uma matriz apoplástica derivada da planta (Bonfante-Fasolo \& Perotto, 1990; Bonfante-Fasolo \& Perotto, 1992; Smith \& Gianinazzi-Pearson, 1988). O periodo de vida de um arbúsculo é de 5 a 10 dias, sendo que após este período ele colapsa e se decompõe, deixando a célula funcional e capaz de ser infectada novamente (Alexander et al., 1988; Alexander et al., 1989). Algumas espécies de FMAs também formam estruturas chamadas vesículas, as quais teriam como função o armazenamento de lipídios (Smith \& Gianinazzi-Pearson, 1988).

Durante a colonização do córtex radicular, as hifas fúngicas desenvolvem-se extensivamente no solo. Este micélio externo tem papel importante nas MAs já que entre suas funções incluem-se a aquisição de nutrientes minerais do solo e a subsequente translocação para as plantas, colonização de outras raízes e, em muitos casos, produção 
de esporos. Além destas funções para a simbiose, o micélio externo contribui para a agregação das partículas do solo e aumento da estabilidade dos agregados, provavelmente através de glicoproteinas produzidas pela hifa (Wright et al., 1996; Wrigth \& Upadhyaya, 1996).

A infectividade dos FMAs e a eficiência do estabelecimento da simbiose são afetados por diversos fatores. Dentre os fatores químicos do solo, o nível de fósforo é o que mais influe nas MAs, afetando, principalmente, o estabelecimento da simbiose. Em última análise, altos níveis de $\mathbf{P}$ na planta inibem o estabelecimento das MAs (Silveira, 1992).

$\mathrm{O} \mathrm{N}$, principalmente na forma em que é aplicado pode afetar o desenvolvimento de MAs. Pereira et al. (1996) observaram que mudas de diversas espécies arbóreas (fedegoso, cássia-verrugosa, cinamomo e jacarandá-mimoso) apresentaram menores taxas de colonização micorrizica quando adubadas com $\mathrm{N}-\mathrm{NH}_{4}{ }^{+}$, em relação a adubação com $\mathrm{N}-\mathrm{NO}_{3}{ }^{-}$. Esses dados sugerem que diferentes formas de $\mathrm{N}$ podem ter papel importante no controle da colonização intraradicular.

\subsection{Regulação gênica em MAs}

Dentre os aproximadamente 100.000 genes presentes nos organismos superiores, cerca de 15\% são realmente expressos em uma única célula. Todos os processos biológicos que ocorrerão nesta célula serão, em última análise, conseqüência da expressão desses genes.

Os estudos sobre expressão gênica em MAs iniciaram-se há poucos anos e pouco se sabe sobre os mecanismos moleculares que controlam a formação e/ou a eficiência das MAs (Harrison, 1999). Para o estudo de biologia molecular das MAs têm sido utilizadas diversas estratégias, sendo mais aplicadas atualmente as de citoquímica e de imunocitoquímica, visando, respectivamente, à localização de carboidratos e proteínas (Lambais, 1996). Com o avanço das técnicas de manipulação e análise de DNA/RNA, a identificação e caracterização de genes com expressão diferencial durante 
a simbiose podem ser feitas com relativa facilidade, e contribuir para o entendimento dos mecanismos que regulam as MAs.

Em muitas interações entre plantas e fungos patogênicos, a invasão dos tecidos vegetais pelo fungo resulta na rápida ativação de mecanismos de defesa vegetal, os quais podem inibir o desenvolvimento da associação patogênica. Em MAs, a indução do sistema de defesa vegetal é transiente (Harrison, 1999). Em Allium porrum, as enzimas quitinase e peroxidase mostraram um aumento transitório na expressão durante os estágios iniciais de desenvolvimento da MA. Contudo, essas atividades na associação micorrízica bem estabelecida foram notadamente mais baixas que nos controles nãocolonizados (Spanu et al., 1989; Spanu \& Bonfante-Fasolo, 1988).

Observações similares foram feitas, posteriormente, em raízes de feijão e de tabaco, onde a colonização foi acompanhada por aumento transitório e posterior supressão dos níveis de transcritos e das atividades de quitinase, $\beta-1,3$ endoglucanase e chalcone isomerase (enzima da biossíntese de isoflavonóides) (David et al., 1998; Lambais \& Mehdy, 1993). Estes dados sugerem que a regulação destas enzimas ocorre na transcrição dos genes, uma hipótese que também é suportada por estudos da expressão de genes codificando enzimas da via de biossíntese de isoflavonóides em espécies de Medicago.

Medicago sativa e Medicago truncatula respondem ao ataque por fungos patogênicos com a rápida indução de genes e enzimas da via biossintética de isoflavonóides, resultando na produção da fitoalexina medicarpina. Ao contrário, durante a colonização de raízes de Medicago por FMAs foi observada supressão do gene codificando isoflavona redutase (IFR), a penúltima enzima da biossíntese da medicarpina, com consequente bloqueio no acúmulo da fitoalexina (Harrison \& Dixon, 1993; Volpin et al., 1995). Através de hibridização in situ, foi observado que a supressão do acúmulo de mRNAs codificando IFR ocorre exclusivamente em células contendo arbúsculos, indicando que este é um efeito específico e localizado (Harrison \& Dixon, 1993). Investigações em raízes de soja colonizadas com isolados diferentes de $G$. intraradices sugerem que a capacidade de supressão da expressão de endoquitinases esta relacionada com a infectividade dos diferentes isolados. Isolados mais infectivos têm 
maior capacidade de induzir maior supressão de genes de defesa vegetais (Lambais \& Mehdy, 1996).

O acúmulo de fitoalexinas ocorre de maneira transitória nos estágios iniciais do desenvolvimento das MAs ou é induzido tardiamante (Harrison \& Dixon, 1993; Wyss et al., 1991). Em raizes de alfafa colonizadas por $G$. intraradices, a indução transitória seguida pela supressão da atividade das enzimas fenilalanina amônia liase e chalcona isomerase, e a acumulação de seus respectivos mRNAs têm sido observada (Volpin et al., 1994; Volpin et al., 1995). A indução do acúmulo de mRNA codificando chalcone sintase em raizes de Medicago truncatula colonizadas por Glomus versiforme limita-se a células contendo arbúsculos (Harrison \& Dixon, 1994). Indução do sistema de defesa vegetal é também observado em raízes de plantas não-hospedeiras de FMAs ou em mutantes incapazes de desenvolver a associação simbiótica (Allen et al., 1989; Douds et al., 1998).

Estes resultados sugerem que antes de serem reconhecidos como simbiontes, os FMAs induzem respostas de defesa, embora atenuadas se comparadas com as respostas de defesa induzidas por patógenos. Assim, o reconhecimento da compatibilidade entre os simbiontes previne a indução de respostas de defesa. Evidências adicionais suportam a hipótese de que reconhecimento e a não-indução das respostas de defesa são necessários para o sucesso da colonização micorrízica, principalmente, em mutantes de ervilha lócus $a$ myc $(-1)$, nos quais o sistema de defesa é induzido, prevenindo a penetração do fungo (Gollotte et al., 1993).

Embora a supressão das respostas de defesa da planta pareça ter ocorrência generalizada nas MAs, esta supressão, aparentemente, não é necessária para o estabelecimento da simbiose. Nicotiana tabacum e Nicotiana sylvestris expressando excesso de quitinases e glucanases formam MAs da mesma forma que os controles (Vierheilig et al., 1995; Vierheilig et al. 1993). Em contraste, a super-expressão destas proteínas de defesa inibe o crescimento de Rhizoctonia solani nas raízes. É possível que outras proteínas de defesa, envolvidas no controle do desenvolvimento das MAs, sejam co-reguladas como quitinases e $\beta$-1,3-glucanases ou que isoformas específicas devam ter sua expressão regulada somente em células infectadas. 
Além da regulação de genes de defesa em MAs, observa-se também a regulação de outros genes, muitos deles envolvidos com a nutrição mineral das plantas. Em M. truncatula, foi observado que quatro genes induzidos por deficiência de fósforo, incluindo dois genes transportadores de fosfato, um gene de função desconhecida (Mt4) e um homólogo a uma fosfatase ácida foram suprimidos após a colonização das raizes pelo FMA (Burleigh \& Harrison, 1997).

Em plantas de milho micorrizadas, um gene codificando uma nitrato redutase (NR) foi clonado e seqüenciado. A análise da expressão desse gene indicou que o nível de seus mRNAs era menor em raizes e brotos de plantas micorrizadas do que no controle não-inoculado. Através de hibridização in situ, mRNAs homólogos ao gene de NR clonado foram localizados em células contendo arbúsculos, mas não em células contendo vesículas (Kaldorf et al., 1998).

Ditt (1997) estudando a ocorrência de genes com expressão diferencial na associação entre $G$. intraradices e raízes de tabaco, identificou e clonou um gene homólogo a genes codificando proteínas acessórias da urease (ureG) em diferentes bactérias. Esse gene ureG putativo é induzido em raízes micorrizadas e pode estar envolvido no controle do desenvolvimento da simbiose ou do metabolismo de $\mathrm{N}$ nas plantas.

\subsection{Urease}

A urease de feijão foi a primeira enzima a ser cristalizada, e cerca de 50 anos mais tarde, ela foi apresentada como a primeira metaloenzima dependente de Ni (Sirko $\&$ Brodzik, 2000). Atividades de ureases já foram identificadas em plantas (Dixon et al., 1975; Hine \& Sprent, 1988; Torisky et al., 1994) e fungos (Crippa et al., 1987; Petruccioli \& Federici, 1992; Ismail \& Abdel-Sater, 1994; Mackay \& Pateman, 1982), incluindo fungos ectomicorrízicos, constituindo-se em um parâmetro para a identificação destes (Hutchison, 1990). Em todos estes organismos, a urease possue estruturas e mecanismos de catálise similares (Sirko \& Brodzik, 2000). 
As ureases são responsáveis pela degradação da uréia a amônio, passo intermediário no metabolismo da arginina (Figura 1). Além disso, estão presentes também em plantas leguminosas noduladas, as quais transportam nitrogênio na forma de ureídeos. O catabolismo de ureídeos produz uréia como intermediário (Tomas \& Schrader, 1981). Na leguminosa arbórea Cassia fasciculata foram detectados elevados teores de ureídeos e altas atividades de urease nos nódulos. É interessante notar que este teor de ureídeos foi maior em nódulos de plantas que também foram colonizadas por FMAs, quando comparado com nódulos de plantas não-micorrizadas (Lynd \& Ansman, 1994).

Além do papel no metabolismo do $\mathrm{N}$ em diversos organismos procariotos e eucariotos, existem relatos na literatura que sugerem o envolvimento da urease como fator de patogenicidade em diversos microrganismos (Mobley \& Hausinger, 1989; Cole et al., 1996; Cox et al., 2000). A urease produzida em grande quantidade pela bactéria Helicobacter pylori (agente causal da gastrite crônica) é essencial para a patogenicidade, infecção e desenvolvimento da doença, como é evidenciado pela incapacidade de mutantes urease-negativos em produzir doenças em ratos (McGee et al., 1999).

A ativação da urease é um processo complexo. Em bactérias, várias proteínas acessórias da urease são essenciais para a incorporação de níquel no centro ativo da proteína. A incorporação do Ni na urease é feita pelas proteínas acessórias da urease. Em Klebsiella aerogenes, os genes codificando urease foram bem caracterizados e estão organizados em um operon contendo quatro genes acessórios (ureD, ureE, ureF e ureG) (Kim, Yang \& Lee, 1999). A deleção destes genes acessórios resulta na síntese de urease inativa, deficiente em Ní (Mulrooney \& Hausinger, 1990; Lee et al., 1992). Comparativamente, em plantas conhece-se pouco sobre o processo de ativação e as enzimas envolvidas. Em tomate foram clonados 5 cDNAs diferentes codificando isoformas da proteína acessória da urease $\mathrm{G}$ (ureG). A análise de expressão do mRNA e dos níveis de proteínas indicaram a presença da ureG em quase todos os tecidos examinados, suportando a hipótese de ubiqüidade da expressão de urease (Witte et al., 2001). 


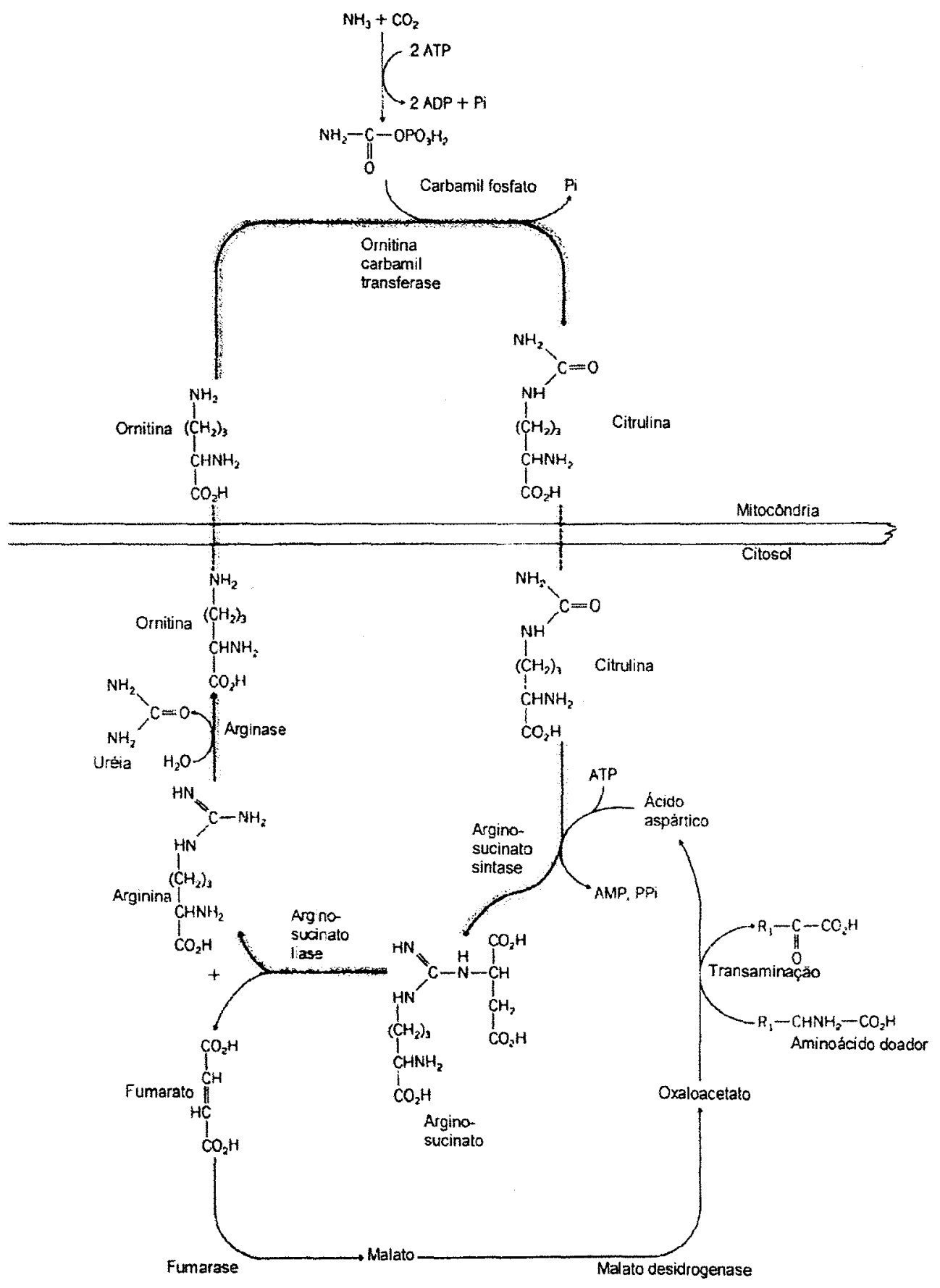

Figura 1 - Ciclo da uréia, em detalhes. 
Em MAs, o papel das ureases, bem como a relação dessa atividade enzimática com o desenvolvimento e ou eficiência da simbiose não são conhecidos. A indução de um gene codificando uma proteína acessória (ureG) em MAs (Ditt, 1997) sugere que atividades de ureases podem ser fatores determinantes no controle desses processos. Aumentos das atividades de ureases poderiam contribuir para o aumento localizado da concentração de $\mathrm{CO}_{2}$, facilitando o crescimento intrarradicular. Alternativamente, aumentos da atividade de urease podem estar associados a alterações do metabolismo de $\mathrm{N}$, um aspecto pouco estudado em MAs.

\subsection{Metabolismo de nitrogênio em plantas micorrizadas}

A importância dos FMAs na nutrição fosfatada de seus hospedeiros é um fenômeno bem documentado, mas o significado da ocorrência da associação micorrizica para a assimilação de nitrogênio é, ainda, pouco claro (Smith et al., 1985; Azcón et al., 1992). Várias evidências da contribuição das MAs para a absorção (Ames et al., 1984; Bago et al., 1996; Johansen et al., 1996) e assimilação (Smith et al., 1985; Azcón et al., 1992; Cliquet \& Stewart, 1993) de N mineral, no entanto, têm sido apresentadas.

Micorrizas arbusculares são particularmente importantes para a aquisição de nutrientes que apresentam baixa mobilidade na solução do solo com o $\mathrm{P}, \mathrm{Cu}$ e $\mathrm{Zn}$. Porém, podem ser importantes também para a absorção de $\mathrm{NH}_{4}{ }^{+}$, o qual normalmente encontra-se adsorvido aos colóides do solo (Johansen et al., 1993). Absorção e assimilação do $\mathrm{N}$-inorgânico pelo fungo são pré-requisitos para a translocação e a transferência para as plantas. Como o $\mathrm{NH}_{4}{ }^{\top}$ está freqüentemente presente em concentrações muito baixas no solo imagina-se que a assimilação dependa da atividade da glutamina sintetase (GS) e glutamato sintetase (GOGAT), tanto quanto glutamato desidrogenase (GDH), devido a alta afinidade da GS por $\mathrm{NH}_{4}{ }^{+}$(Miflin \& Lea, 1976). A atividade de GS é maior em raízes micorrizadas devido à contribuição das enzimas do fungo. $\mathrm{O}$ aumento da concentração de fósforo nas plantas resulta em pequeno aumento na atividade de GS, confirmando a importante contribuição do fungo. Em contraste, a atividade GDH não apresenta relação direta com a colonização (Smith et al., 1985). 
Muitos estudos têm demonstrado o transporte de $\mathrm{N}$ (orgânico e inorgânico) pelas hifas de FMAs. Frey \& Schuepp (1993) realizaram um experimento no qual plantas de milho foram cultivadas em vasos divididos por uma malha de nailon fina, nos quais apenas as hifas dos fungos micorrizicos tinham acesso ao compartimento onde aplicava-se fontes orgânicas e inorgânicas de nitrogênio marcadas com ${ }^{15} \mathrm{~N}$. As plantas micorrizadas apresentaram maior absorção do $\mathrm{N}$ do que as plantas não-micorrizadas, sendo que este aumento ocorreu devido à translocação do $\mathrm{N}$ pela hifa do fungo.

Um aumento na absorção de $\mathrm{N}$ nas raízes micorrizadas (sendo diretamente mediada pelos fungos ou não) pode ser importante, para compensar a perda relativa da área de absorção radicular em plantas micorrizadas com reduzida relação raiz:parte aérea (Smith \& Read, 1997)

A atividade de NR têm sido detectada, embora em níveis muito baixos, em esporos de Glomus mosseae e Glomus macrocarpum (Ho \& Trappe, 1975). Muitos fungos que reduzem $\mathrm{NO}_{3}{ }^{\circ}$ possuem uma enzima dependente de $\mathrm{NADP}$, Oliver et al. (1983), avaliando a atividade de NR dependente de NAD e NADP em raízes micorrizadas de Trifollium subterraneum com $80 \%$ de colonização, observaram que embora não exista atividade dependente de NADP, a atividade de NR dependente de NAD estava presente. Esta enzima, mais comum em plantas superiores do que em fungos, aumenta nas plantas colonizadas e naquelas que receberam $P$ adicional.

No caso da NR, os efeitos da infecção micorrízica aparentam ser inteiramente devidos ao aumento da concentração de $\mathrm{P}$ na planta, de acordo com o requerimento desta enzima por P (Beever \& Burns, 1980). Não há evidência de que a atividade da NR fúngica (detectada em esporos) seja importante para a simbiose (Smith \& Gianinazzi-Pearson, 1988). Mas, recentemente, foi mostrada a indução de mRNAs de uma NR fúngica em arbúsculos de $G$. intraradices em raízes de milho (Kaldorf et al., 1998).

As atividades de GS e NR são maiores na parte aérea de plantas micorrizadas, comparando com controles não micorrizados, mas não nas raizes de plantas de centeio. A incorporação de ${ }^{15} \mathrm{~N}$ é maior em, glutamato, alanina e ácido $\gamma$ aminobutírico, não havendo diferença entre plantas controle e plantas micorrizadas. A 
incorporação de ${ }^{15} \mathrm{~N}$ na serina foi 4 vezes maior em raízes micorrizadas do que nos controles não-micorrizados. Na parte aérea, o acúmulo de aminoácidos foi maior em plantas micorrizadas que no controle. Adicionalmente, a incorporação de ${ }^{15} \mathrm{~N}$ foi dez vezes maior entre 2 a 4 horas após o início do experimento para serina e glutamato na parte aérea de plantas micorrizadas do que nas plantas controle (Faure et al., 1998).

A colonização micorrízica pode resultar em aumento do crescimento e do conteúdo total de $\mathrm{N}$ das plantas, independente das fontes (nitrato, aspartato e serina). Digferenças significativas nos perfis de acumulação dos aminoácidos entre as plantas e controle não-micorrizados não foram observadas (Cliquet et al., 1997). Em contraste, plantas de soja adubadas com $\mathrm{N}$-mineral tiveram diminuição do conteúdo total de aminoácidos livres nas folhas quando colonizadas por Glomus fasciculatum, mas apresentaram aumento do teor de glutamina (Pacovsky, 1989).

Em plantas de milho inoculadas com G. mosseae (submetidas ou não a estresse hídrico) observou-se menores teores de aminoácidos livres nas folhas do que em plantas não-inoculadas (Schellenbaum et al., 1998). Já plantas de milho inoculadas com o fungo G. intraradices apresentaram maiores teores de aminoácidos livres na parte aérea do que plantas não-inoculadas (Subramanian \& Charest, 1998). Estes resultados sugerem que tanto a inoculação como a espécie de FMA inoculado podem alterar o metabolismo de $\mathrm{N}$ nas plantas.

Em morangueiros cultivados in vitro, a inoculção do fungo micorrízico $G$. intraradices não causou diferenças significativas no teor total de aminoácidos livres nas folhas, mas causou aumentos significativos na concentração de asparagina em plantas sob condição de estresse hídrico (Hernández-Sebastiá et al., 2000). Já em Pittosporum toriba colonizadas por G. mosseae apresentaram maiores concentrações de aminoácidos livres na seiva do xilema do que plantas não-colonizadas (Coxwell \& Johnson, 1985).

Os dados da literatura sugerem que a inoculação de FMAs pode alterar tanto a absorção quanto a assimilação de $\mathrm{N}$ pelas plantas. 


\section{MATERIAL E MÉTODOS}

\subsection{Instalação do experimento}

Sementes de fumo (Nicotiana tabacum cv. Petit Havana) foram plantadas em caixas plásticas com células cônicas contendo substrado composto por areia lavada + vermiculita (2:1). A adubação foi feita com solução de Hoagland \& Arnon completa (Sarruge, 1975).

Seis semanas após o plantio foi feito o transplante para vasos com capacidade para $3 \mathrm{~kg}$ e com o mesmo substrato. Todos os vasos receberam adubação básica composta por $60 \mathrm{mg}$ de $\mathrm{P}$ na forma de $\mathrm{KH}_{2} \mathrm{PO}_{4}, 180 \mathrm{mg}$ de $\mathrm{K}$ na forma de $\mathrm{KCl}$, $120 \mathrm{mg}$ de $\mathrm{Ca}$ na forma de $\mathrm{CaCl}_{2}$ e $60 \mathrm{mg}$ de $\mathrm{Mg}$ na forma de $\mathrm{MgSO}_{4} \cdot 7 \mathrm{H}_{2} \mathrm{O}, 1 \mathrm{~mL}$ de solução de Fe-EDTA de Hoagland \& Arnon e $1 \mathrm{~mL}$ de solução de micronutrientes (B, $\mathrm{Cu}, \mathrm{Mn}$ e $\mathrm{Zn}$ ) de Hoagland \& Arnon.

A adubação nitrogenada foi feita com a aplicação de $50 \mathrm{mg} \mathrm{kg}^{-1}$ na ocasião do transplantio. Três semanas após o transplantio realizou-se nova adubação com $50 \mathrm{mg}$ $\mathrm{kg}^{-1}$ para os tratamentos 100 e $150 \mathrm{mg} \mathrm{kg}^{-1}$. Para completar a dose de $150 \mathrm{mg} \mathrm{kg}^{-1}$ fez-se mais uma adubação com $50 \mathrm{mg} \mathrm{kg}^{-1}$, seis semanas após o plantio. As fontes de nitrogênio utilizadas foram uréia ou sulfato de amônio, o pH das soluções utilizadas não diferiram entre si apresentando valor de 5,6.

A inoculação com os fungos micorrizicos G. intraradices e Glomus clarum foi realizada no momento do transplantio. $\mathrm{O}$ inóculo (aproximadamente $10 \mathrm{~mL}$ ) constou de uma mistura de solo, esporos fúngicos e fragmentos de hifas e raizes de Brachiaria colonizadas. 
O delineamento experimental utilizado foi inteiramente casualizado, em esquema fatorial $3 \times 2 \times 3$ com 4 repetições, sendo 3 os níveis do fator "DOSES DE N" $\left(50,100\right.$ e 150 mg.kg $\left.{ }^{-1}\right), 2$ os níveis do fator 'FONTES DE N" (uréia e sulfato de amônio) e 3 os níveis do fator "FUNGOS MICORRÍZICOS" (sem fungo, G. clarum e G. intraradices), perfazendo um total de 72 unidades experimentais.

O experimento foi mantido na casa-de-vegetação do Departamento de Solos e Nutrição de Plantas da ESALQ/USP por oito semanas.

\subsection{Análises laboratoriais}

\subsubsection{Determinação da massa da matéria seca da parte aérea e do sistema radicular}

Para determinação da massa da matéria seca , a parte aérea e as raízes foram separadas, lavadas com água destilada e colocadas para secar em estufa a $70^{\circ} \mathrm{C}$ até massa constante.

\subsubsection{Avaliação da colonização micorrízica}

A determinação da porcentagem de colonização de raízes foi feita pelo método descrito por Philips \& Hayman (1970). As raízes foram descoloridas com solução de $\mathrm{KOH} 10 \%$ em banho-maria a $90^{\circ} \mathrm{C}$ por 45 min, lavadas com água corrente, e acidificadas com solução de $\mathrm{HCl} 10 \%$ por $3 \mathrm{~min}$. Em seguida, as raízes foram coloridas com solução de azul-de-tripano $0,05 \%$ em lactoglicerol por 5 min a $90^{\circ} \mathrm{C}$. A avaliação da colonização intraradicular foi feita por microscopia, determinando-se a presença de estruturas fúngicas (hifas, arbúsculos e vesículas) no tecido cortical, em placas reticuladas, segundo o método descrito por Giovanetti \& Mosse (1980).

\subsubsection{Extração e quantificação de proteínas}


A extração de proteínas foi feita de acordo com o método descrito por Lambais \& Mehdy (1993) e adaptado por Ríos-Ruiz (1998) no qual aproximadamente 3 $\mathrm{g}$ de raízes foram maceradas em nitrogênio líquido e homogeneizadas em $9 \mathrm{~mL}$ de solução de extração contendo tampão fosfato $100 \mathrm{mM}(\mathrm{pH} 7,5)$, EDTA (etilenodiamino tetracético) $1 \mathrm{mM}$ e PMSF (parametilsulfonilfluoreto) $1 \mathrm{mM}$. O extrato bruto foi obtido através de centrifugação a $20000 \mathrm{~g}$ por $20 \mathrm{~min}$ a $4^{\circ} \mathrm{C}$ ). Este extrato foi dividido em alíquotas de $500 \mu \mathrm{L}$ e armazenado a $-80^{\circ} \mathrm{C}$

A quantificação do conteúdo de proteínas foi feita pelo método de Bradford (1976), utilizando-se o procedimento em microplacas do kit comercial BioRad e albumina de soro bovino (ASB) como padrão. Para tanto, o reagente do kit para determinação de proteínas da Bio-Rad foi diluído em 4 partes de água e $200 \mu \mathrm{L}$ desta solução foram distribuidos em microplaca. Misturou-se $10 \mu \mathrm{L}$ de cada amostra com a reação de ensaio e fez-se a determinação da absorbância a $595 \mathrm{~nm}$ em espectrofotômetro.

\subsubsection{Determinação das atividades de ureases}

A determinação da atividade de urease foi feita utilizando-se $500 \mu \mathrm{L}$ do extrato de proteínas obtido no item 3.2.2., em $500 \mu \mathrm{L}$ de tampão Tris-maleato $100 \mathrm{mM}$, EDTA $1 \mathrm{mM}(\mathrm{pH} \mathrm{7,0)}$, uréia 50mM (Miksch et al.,1994). As amostras foram incubadas por $6 \mathrm{~min}$ a $37^{\circ} \mathrm{C}$, e a quantidade de amônia formada foi determinada por espectrofotometria, utilizando-se o kit Sigma-Amônia (Sigma). Onde $100 \mu \mathrm{L}$ da solução de ensaio (2-oxoglutarato $3 \mathrm{mM}$, NADPH $0,23 \mathrm{mM}$ ) foi misturada com $10 \mu \mathrm{L}$ de amostra em uma microcubeta de quartzo para espectrofotômetro. A absorbância inicial foi então determinada. O decréscimo na absorbância a $340 \mathrm{~nm}$, devido à oxidação do NADPH na presença de L-glutamato desidrogenase $(1200 \mathrm{U} / \mathrm{mL})$ foi, então, determinada.

\subsubsection{Determinação de aminoácidos}


Para a determinação dos aminoácidos, os tecidos da parte aérea foram liofilizados, macerados em nitrogênio líquido e extraídos em $4 \mathrm{~mL}$ do tampão de extração (metanol/clorofórmio/água $-12 \mathrm{~mL} / 5 \mathrm{~mL} / 3 \mathrm{~mL}$ ), de acordo com o procedimento descrito por Bielesky \& Turner (1966). O material obtido foi extraído por 2 horas a $4^{\circ} \mathrm{C}$ e centrifugado a $2500 \mathrm{rpm}$ por $20 \mathrm{~min}$ a $4^{\circ} \mathrm{C}$. Ao sobrenadante coletado foi adicionado 2 $\mathrm{mL}$ de clorofórmio (100\%) e procedeu-se nova centrifugação $\left(2500 \mathrm{rpm} / 20 \mathrm{~min} / 4^{\circ} \mathrm{C}\right)$. O sobrenadante obtido foi levado ao liofilizador "overnight" e o pélete obtido foi ressuspendido em $0,5 \mathrm{~mL}$ de $\mathrm{H}_{2} \mathrm{O}$.

Um volume de $10 \mu \mathrm{L}$ da fração aquosa foi misturado a $10 \mu \mathrm{L}$ do reagente OPA (o-phthaldialdehyde). Após três minutos, $10 \mu \mathrm{L}$ da mistura de derivatização foi injetada no HPLC. A separação dos aminoácidos ocorreu em coluna Water Spherisosb (Supelco) ODS-2 acoplada a um sistema HPLC Äkta purifier (Amershan harmacia Biotech).

A coluna foi eluída a uma taxa de $0,8 \mathrm{ml} / \mathrm{min}$, usando um gradiente formado por misturas crescentes de 65\% metanol com tampão fosfato pH 7,25 (50 mM NaOAc, $50 \mathrm{mM} \mathrm{Na}_{2} \mathrm{HPO}_{4}, 1,5 \mathrm{~mL}$ Hac, $20 \mathrm{~mL}$ tetrahydrafuran, $20 \mathrm{ml} \mathrm{MeOH}$ em $1 \mathrm{~L}$ de água). $\mathrm{O}$ efluente da coluna foi monitorado pelo detector de fluorescência Shimadzu (modelo F350) operando a $250 \mathrm{~nm}$ (comprimento de excitação) e a $480 \mathrm{~nm}$ (comprimento de emissão). Os dados foram guardados e processados pelo software Pharmacia Unicorn.

\subsubsection{Determinação de nutrientes na parte aérea}

Para a determinação dos nutrientes da parte aérea, as plantas foram enviadas para o Laboratório de Análise de Solos e Plantas da ESALQ - USP e as determinações foram feitas segundo metodologia de Malavolta et al. (1989).

Para a determinação de nitrogênio, as amostras foram submetidas a digestão sulfúrica (ácido sulfúrico concentrado e sais catalizadores) a quente. A concentração de $\mathrm{N}$ no extrato obtido foi feita por semi-micro Kjeldahl. 
Para a determinação dos demais nutrientes as amostras foram submetidas a digestão nítrica-perclórica. A concentração de $\mathrm{P}$ e $\mathrm{S}$ no extrato foi determinada por colorimetria e turbidimetria, respectivamente. A concentração de $\mathrm{Ca}, \mathrm{Mg}, \mathrm{Cu}, \mathrm{Fe}, \mathrm{Mn}$ e $\mathrm{Zn}$ foi determinada por absorção atômica. A concentração de $\mathrm{K}$ foi determinada por fotometria de emissão de chama.

Para a determinação do Boro as amostras foram digeridas por via seca (incineração). As cinzas obtidas forma dissolvidas em $\mathrm{HCl} 0,1 \mathrm{~N}$ e a determinação da concentração de $B$ nesta solução foi feita por colorimetria da azometina $H$.

\subsubsection{Análises estatísticas}

A análise estatística dos dados foi feita com a análise de variância e posterior aplicação do teste F para todos os fatores estudados e suas interações. Quando o teste F foi significativo, aplicou-se o teste de comparação múltiplas (teste de Tukey) com probabilidade $\mathrm{p} 0,05$. O tratamento estatístico dos dados foi efetuado utilizando 0 programa Systat 8,0 . 


\section{RESULTADOS E DISCUSSÃO}

\subsection{Colonização micorrízica}

Os resultados de porcentagem de colonização micorrízica são apresentados na Tabela 1. No geral, G. intraradices foi menos infectivo que G. clarum. Houve efeito significativo da interação dos fatores "DOSES DE N" e "FUNGOS MICORRÍZICOS" $(\mathrm{p}<0,05)$. A porcentagem de colonização micorrízica por $G$. clarum aumentou com o aumento da dose de N. Já, a colonização por $G$. intraradices não foi significativamente afetada pela concentração de $\mathrm{N}$ no substrato de cultivo.

A colonização micorrízica por G. clarum e G. intraradices foi, no geral, maior nos tratamentos com 50 e $100 \mathrm{mg} \mathrm{N}$-uréia $\mathrm{kg}^{-1}$, do que nos tratamentos com as mesmas concentrações de $\mathrm{N}$-sulfato de amônio. Esses dados sugerem que a uréia pode estimular o crescimento fúngico intrarradicular em tabaco.

A hidrólise da uréia produz $\mathrm{CO}_{2}$, o qual pode estimular o crescimento de FMAs e a colonização das raízes de algumas espécies vegetais (Staddon \& Filter, 1998). Em trevo, aumentos na concentração de $\mathrm{CO}_{2}$ não alteraram significativamente a colonização de raizes por Glomus mosseae, mas induziram o aumento do comprimento de raízes colonizadas (Jongen et al., 1996). Estímulo do crescimento micelial de diversas espécies de FMAs pelo aumento da concentração de $\mathrm{CO}_{2}$ também têm sido observado (Sanders et al., 1998). Em concentrações elevadas de $\mathrm{CO}_{2}$, a produção de biomassa fúngica extrarradicular pode ser maior do que a intrarradicular, explicando porque em 
Tabela 1. Porcentagem de colonização de raízes de Nicotiana tabacum por G. clarum ou $G$. intraradices, na presença de diferentes concentrações de $\mathrm{N}$, na forma de uréia ou sulfato de amônio.

\begin{tabular}{lccccc}
\hline Fonte de & Dose & $\mathrm{N}$ & \multicolumn{3}{c}{ Tratamento de inoculação } \\
\cline { 4 - 6 } Nitrogênio & $\left(\mathrm{mg} \mathrm{kg}^{-1}\right)$ & Não-inoculado & G. clarum & G. intraradices \\
\hline Sulfato & de & 50 & $0,0 \% \mathrm{~A} \mathrm{~b}$ & $29,0 \% \mathrm{~B} \mathrm{a}$ & $6,1 \% \mathrm{~A} \mathrm{a}$ \\
amônio & 100 & $0,0 \% \mathrm{~A} \mathrm{~b}$ & $42,3 \% \mathrm{AB} \mathrm{ab}$ & $4,8 \% \mathrm{~A} \mathrm{a}$ \\
& 150 & $0,0 \% \mathrm{~A} \mathrm{~b}$ & $66,8 \% \mathrm{~A} \mathrm{a}$ & $10,0 \% \mathrm{~A} \mathrm{~b}$ \\
\multirow{2}{*}{ Uréia } & 50 & $0,0 \% \mathrm{~A} \mathrm{c}$ & $38,7 \% \mathrm{~B} \mathrm{a}$ & $21,8 \% \mathrm{~A} \mathrm{~b}$ \\
& 100 & $0,0 \% \mathrm{~A} \mathrm{c}$ & $56,6 \% \mathrm{AB} \mathrm{a}$ & $23,5 \% \mathrm{~A} \mathrm{~b}$ \\
& 150 & $0,0 \% \mathrm{~A} \mathrm{~b}$ & $79,5 \% \mathrm{~A} \mathrm{a}$ & $6,3 \% \mathrm{~A} \mathrm{~b}$ \\
\hline
\end{tabular}

Os dados são médias de 4 repetições. Médias seguidas da mesma letra não diferem estatisticamente (teste Tukey, $\mathrm{p}<0,05$ ). Letras maiúsculas são usadas para comparar as médias nas colunas, para cada fonte de nitrogênio. Letras minúsculas são usadas para comparar as médias nas linhas. 
elevadas concentrações de $\mathrm{CO}_{2}$ a indução da colonização intraradicular pode não ser observada (Sanders et al, 1998).

A hidrólise da uréia produz também $\mathrm{NH}_{3}$, o qual pode alterar o $\mathrm{pH}$ da rizosfera, favorecendo o processo de colonização das raizes por certas espécies de FMAs.

\subsection{Biomassa vegetal}

Independentemente da fonte de $\mathrm{N}$ ou de sua concentração, diferenças significativas entre a massa da matéria seca da parte aérea (MSPA) dos tratamentos nãoinoculados e inoculados com G. clarum ou G. intraradices, não foram observadas, indicando que a presença dos fungos não afetou a produção de biomassa aérea pelas plantas (Figura 2). No entanto, plantas não-inoculadas cultivadas na maior dose de sulfato de amônio produziram 26\% menos MSPA, quando comparadas com as plantas cultivadas na mesma dose de uréia $(\mathrm{p}<0,05)$ (Figura 2).

A matéria seca do sistema radicular (MSSR) não foi afetada significativamente pela inoculação com os fungos G. clarum ou G. intraradices, em relação aos controles não-inoculados $(\mathrm{p}<0,05)$ (Figura 3). Aumentos significativos da MSSR foram observados com o aumento da concentração de $\mathrm{N}$ adicionado, tanto na forma de sulfato de amônio, quanto uréia $(\mathrm{p}<0,05)$. Houve também diferença significativa entre as fontes utilizadas, sendo que as plantas cultivadas com sulfato de amônio apresentaram MSSR menor do que aquelas cultivadas com uréia. Como no caso da MSPA, efeito tóxico ou inibitório do sulfato de amônio na MSSR de tabaco pôde ser observado.

Allen \& Smith (1986) observaram que plantas de mamona (Ricinus communis) também apresentaram diminuição do crescimento quando cultivadas em alta concentração de $\mathrm{NH}_{4}{ }^{+}\left(8 \mathrm{~mol} \mathrm{~m}^{-3}\right.$, aproximadamente $\left.112 \mathrm{mg} \mathrm{N} \mathrm{kg}^{-1}\right)$, sugerindo que altas concentrações de sulfato de amônio pode ter efeito inibitório ou tóxico ao desenvolvimento das plantas.

Várias hipóteses têm sido propostas para explicar o menor crescimento de plantas cultivadas na presença de altas concentrações de $\mathrm{NH}_{4}{ }^{+}$, em relação a outras formas de $\mathrm{N}$. Altas concentrações de $\mathrm{NH}_{4}{ }^{+}$podem induzir a deficiência de íons metálicos. $\mathrm{O} \mathrm{NH}_{4}{ }^{+}$ 


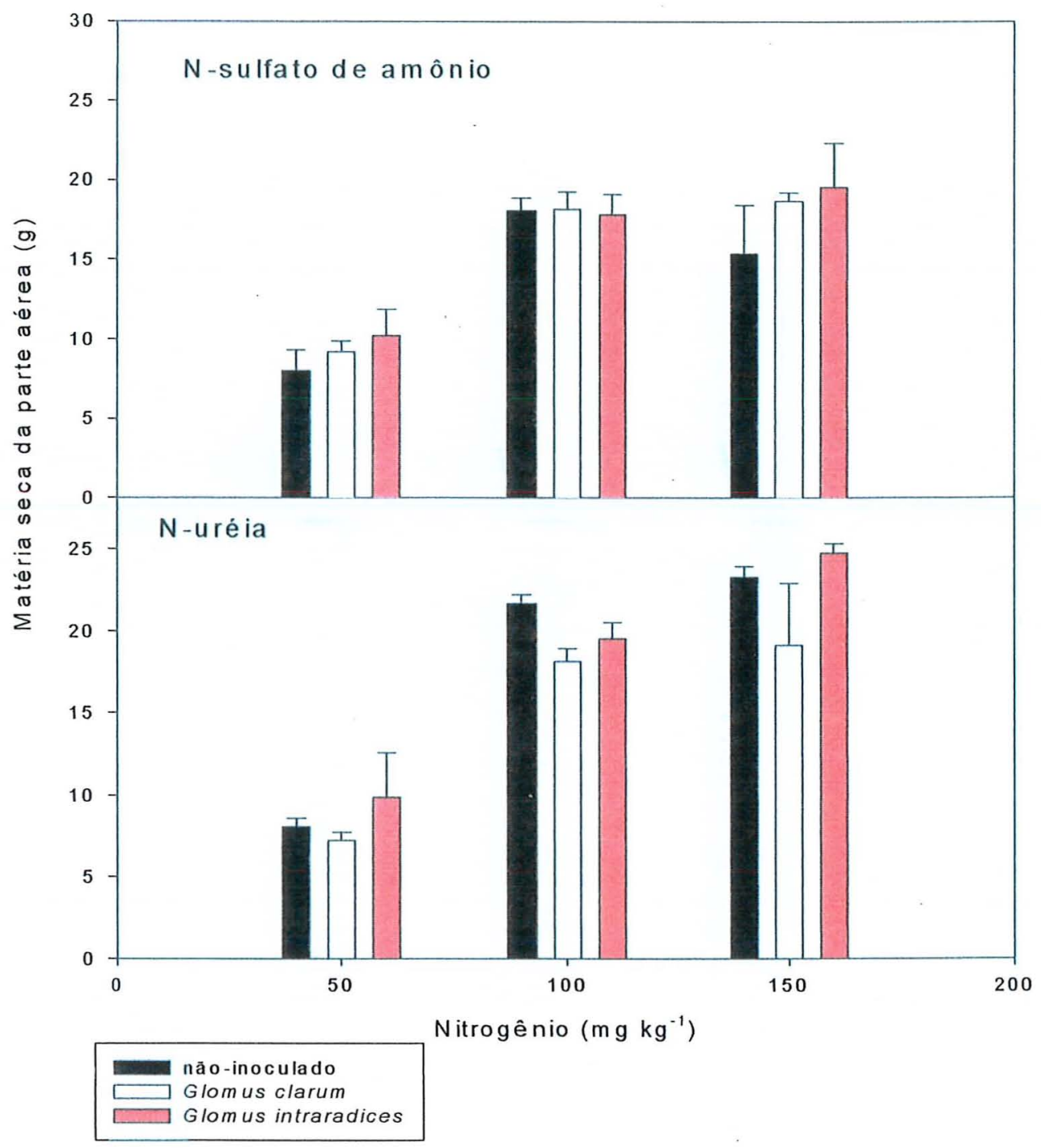

Figura 2 - Matéria seca da parte aérea de Nicotiana tabacum cultivada na presença de sulfato de amônio ou uréia como fonte de nitrogênio, e inoculada com fungos micorrízicos arbusculares. Os dados são médias de 4 repetições \pm desvio padrão da média. 


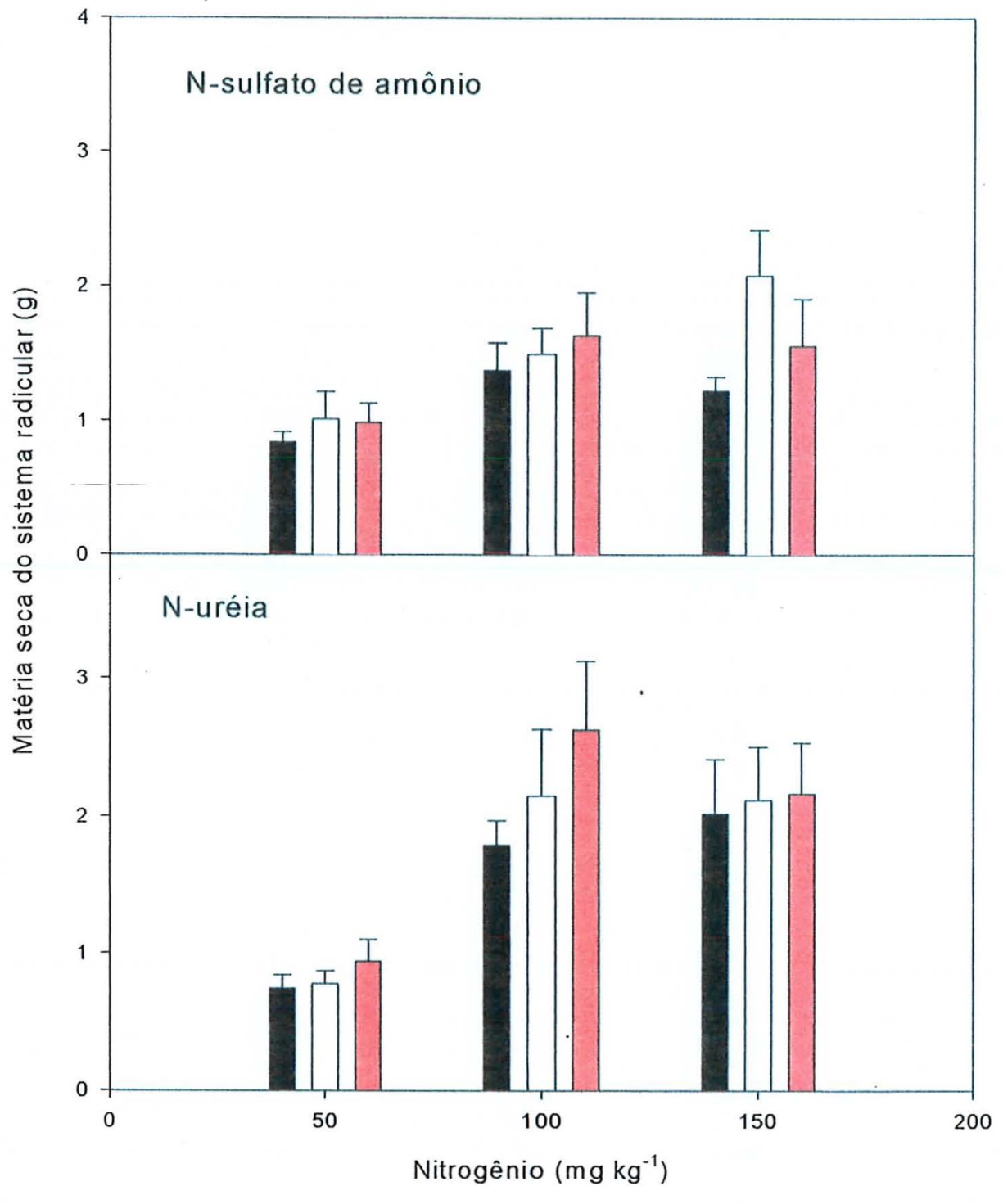

não-inoculado

Glomus clarum

Glomus intraradices

Figura 3 - Matéria seca do sistema radicular de Nicotiana tabacum cultivadas na presença de sulfato de amônio ou uréia como fonte de nitrogênio, e inoculadas com fungos micorrízicos arbusculares. Os dados são médias de 4 repetições \pm desvio padraõ da média. 
pode também inibir o crescimento vegetal pela acidificação do meio, bem como alteração do $\mathrm{pH}$ intracelular e do balanço osmótico. $\mathrm{O}$ acúmulo de $\mathrm{NH}_{4}{ }^{+}$nas folhas pode causar um desbalanceamento da fosforilação e do transporte de elétrons. Altas concentrações de $\mathrm{NH}_{4}{ }^{+}$nas folhas podem, também, alterar o metabolismo de poliaminas e fitormônios, interferindo no crescimento vegetal (Gerendas et al., 1998).

Acredita-se que tanto as plantas cultivadas em solo com $\mathrm{N}$-uréia com as cultivadas em solo com $\mathrm{N}$-sulfato de amônio absorvam nitrogênio na forma de $\mathrm{NH}_{4}{ }^{+}$. No entanto, foi observado recentemente que tomateiros cultivados em hidroponia com Nuréia absorvem e translocam $\mathrm{N}$ preferencialmente na forma de uréia e não como $\mathrm{NH}_{4}{ }^{+}$ (Tan et al., 2000). A maior parte do ${ }^{15} \mathrm{~N}$-uréia foi encontrado na parte aérea, ainda na

forma de uréia, não sendo detectado ${ }^{15} \mathrm{~N}_{-} \mathrm{NH}_{4}{ }^{+}$na parte aérea mesmo após 24 horas da adição da uréia ao meio (Tan et al., 2000).

Neste experimento, se o $\mathrm{N}$-uréia foi absorvido e translocado na forma de uréia ou $\mathrm{NH}_{4}{ }^{+}$não foi determinado. A absorção e translocação na forma de $\mathrm{N}$-uréia, poderia explicar o maior crescimento das plantas cultivadas com uréia, quanto comparado com sulfato de amônio.

\subsection{Atividades específicas de ureases nas raízes}

As atividades específicas de ureases nas raízes foram afetadas tanto pela inoculação com FMAs, quanto pela fonte e concentração de $\mathrm{N}$ adicionados (Figura 4). Quando utilizou-se uréia como fonte de $\mathrm{N}$, observou-se um aumento da atividade específica da urease nas raizes das plantas não-inoculadas em função do aumento das concentrações de $\mathrm{N}$ no substrato de cultivo. Resultados similares foram observados por Skokut \& Filner (1980), os quais mostraram que as atividades de urease em células de tabaco XD são mais elevadas em meios contendo maiores concentrações de uréia.

A inoculação com G. clarum proporcionou aumentos significativos das atividades específicas de ureases em meio com $50 \mathrm{mg} \mathrm{N}$-uréia $\mathrm{kg}^{-1}$ substrato, quando comparado com o controle não-inoculado. Já, a inoculação com $G$. intraradices não 


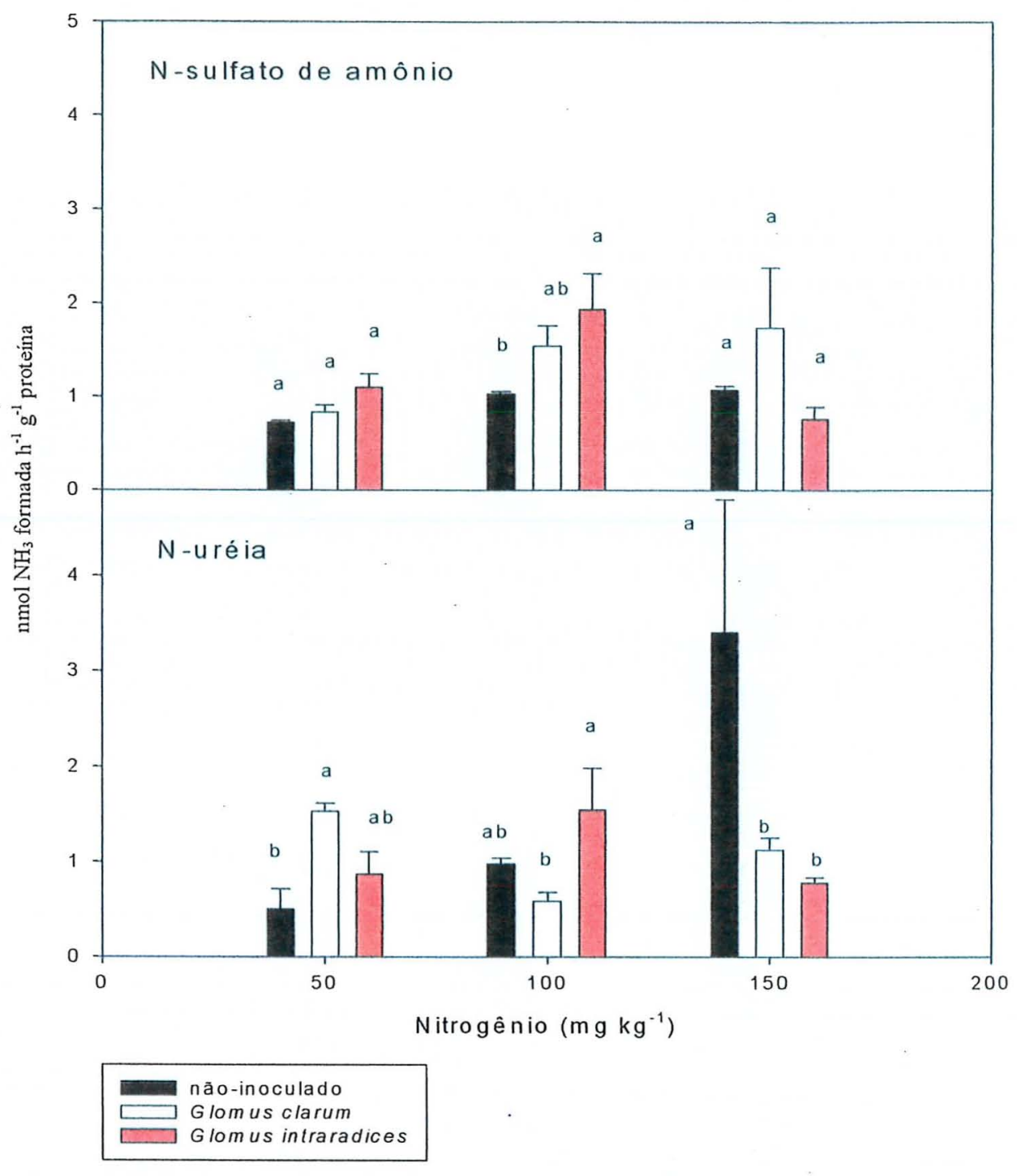

Figura 4 - Atividades específicas de ureases em raizes de Nicotiana tabacum cultivadas na presença de sulfato de amônio ou uréia como fonte de nitrogênio, e inoculadas com fungos micorrízicos arbusculares. Os dados são médias de 4 repetições \pm desvio padrão da média. Médias dos tratamentos de inoculação seguidas por letras iguais não diferem estatisticamente, para a mesma dose e fonte de nitrogênio (Tukey, $\mathrm{p}<0,05$ ). 
causou aumentos significativos das atividades específicas de ureases nas doses 50 e 100 $\mathrm{mg} \mathrm{kg}{ }^{-1} \mathrm{~N}$-uréia substrato, quando comparado com os controles não-inoculados. Em raizes micorrizadas, em substrato com $150 \mathrm{mg} \mathrm{kg}^{-1} \mathrm{~N}$-uréia, as atividades específicas de ureases foram aproximadamente 3 vezes menores que as observadas no controle não inoculado. Em contraste, quando utilizou-se $100 \mathrm{mg}$ de $\mathrm{N}$-sulfato de amônio $\mathrm{kg}^{-1}$, as atividades específicas de ureases em raizes colonizadas com $G$. intraradices foram 1,5 vezes maiores do que no controle não-inoculado $(p<0,05)$ (Figura 3$)$.

Nos tratamentos com sulfato de amônio, a atividade de urease mostrou correlação positiva com a porcentagem de colonização micorrízica $(r=0,38 ; p=0,02)$, sugerindo que a atividade de urease pode afetar a infectividade de FMAs. Nos tratamentos com uréia, essa correlação não foi observada, possivelmente devido ao maior efeito da uréia sobre a atividade específica das ureases. Ureases podem ser importantes determinantes da infectividade de FMAs, pois catalizam a hidrólise da uréia formando $\mathrm{CO}_{2}$, o qual pode estimular o crescimento micelial e o comprimento de rázes colonizadas (Jongen et al., 1996).

Ditt (1997) observou que em raizes de tabaco colonizadas por $G$. intraradices, a expressão de um gene codificando uma proteína acessória urease (UreG) é altamente induzida. A indução de ure $G$ não foi associada a alterações nas atividades de ureases, mas é possível que UreG seja essencial para a síntese de ureases funcionais (Mulrooney \& Hausinger, 1990; Lee et al., 1992). Em outros sistemas biológicos, atividades de ureases estão associados com a virulência de patógenos bacterianos e fúngicos. Em Helicobacter pilori e Cryptococcus neoformans, ureases são essenciais para a infecção de tecidos humanos (Cox et al., 2000; McGee et al., 1999).

Em fungos micorrizicos arbusculares, essa associação não é clara. É possível que ureases, do fungo e/ou da planta, possam alterar as características químicas da rizosfera, facilitando o crescimento fúngico. Porém, novos experimentos devem ser realizados para definir o papel de ureases em MAs. 


\subsection{Concentração de proteínas em extratos de raízes}

A concentração de proteínas em extratos de raízes foi afetada significativamente pela interação entre os fatores "FUNGOS MICORRÍZICOS" e "FONTES DE N" e pela interação entre os fatores "FUNGOS MICORRÍZICOS" e "DOSES DE N" (Figura 5). As raízes das plantas inoculadas com G. intraradices apresentaram os maiores teores de proteínas no extrato, tanto com $150 \mathrm{mg} \mathrm{kg}^{-1} \mathrm{~N}$-uréia quanto com $150 \mathrm{mg} \mathrm{kg}^{-1} \mathrm{~N}$-sulfato de amônio, comparados com os controles nãoinoculados. Já, com $50 \mathrm{mg} \mathrm{kg}^{-1} \mathrm{~N}$-sulfato de amônio, as plantas inoculadas com $G$. intraradices apresentam concentrações de proteínas nos extrato de raizes $235 \%$ inferiores ao controle não-inoculado. Estes resultados são similares aos observados por Pacovsky (1989), onde plantas de soja inoculadas com Glomus fasciculatum, e cultivadas com $42 \mathrm{mg} \mathrm{N}-\mathrm{NH}_{4} \mathrm{NO}_{3} \mathrm{~kg}^{-1}$, apresentaram menores concentrações de proteínas solúveis no sitema radicular.

Aumentos significativos nas concentrações de proteínas em raizes micorrizadas também foram observadas por Subramanian \& Charest (1998), em experimento com plantas de milho adubadas com solução de Hoagland, contendo 210 mg N L ${ }^{-1}$, na forma de $\mathrm{KNO}_{3}$ e $\mathrm{Ca}\left(\mathrm{NO}_{3}\right)_{2}$. Da mesma forma, Arines et al. (1993) detectaram aumentos de 2 a 6 vezes na concentração de proteínas solúveis em raízes de trevo colonizadas por fungos micorrízicos arbusculares.

\subsection{Aminoácidos solúveis na parte aérea}

A concentração de aminoácidos solúveis na parte aérea das plantas pode ser vista na Figura 6. A interação entre "FONTES DE N" e "DOSES DE N" foi a principal causa de variação para a concentração de aminoácidos solúveis na parte aérea das plantas. Concentrações mais elevadas de aminoácidos solúveis foram observadas na parte aérea de plantas não-inoculadas cultivadas com $50 \mathrm{mg} \mathrm{kg}^{-1} \mathrm{~N}$-sulfato de amônio. $\mathrm{Na}$ presença de $50 \mathrm{mg} \mathrm{kg}^{-1}$ de $\mathrm{N}$-sulfato de amônio, a inoculação com G. clarum ou $G$. 


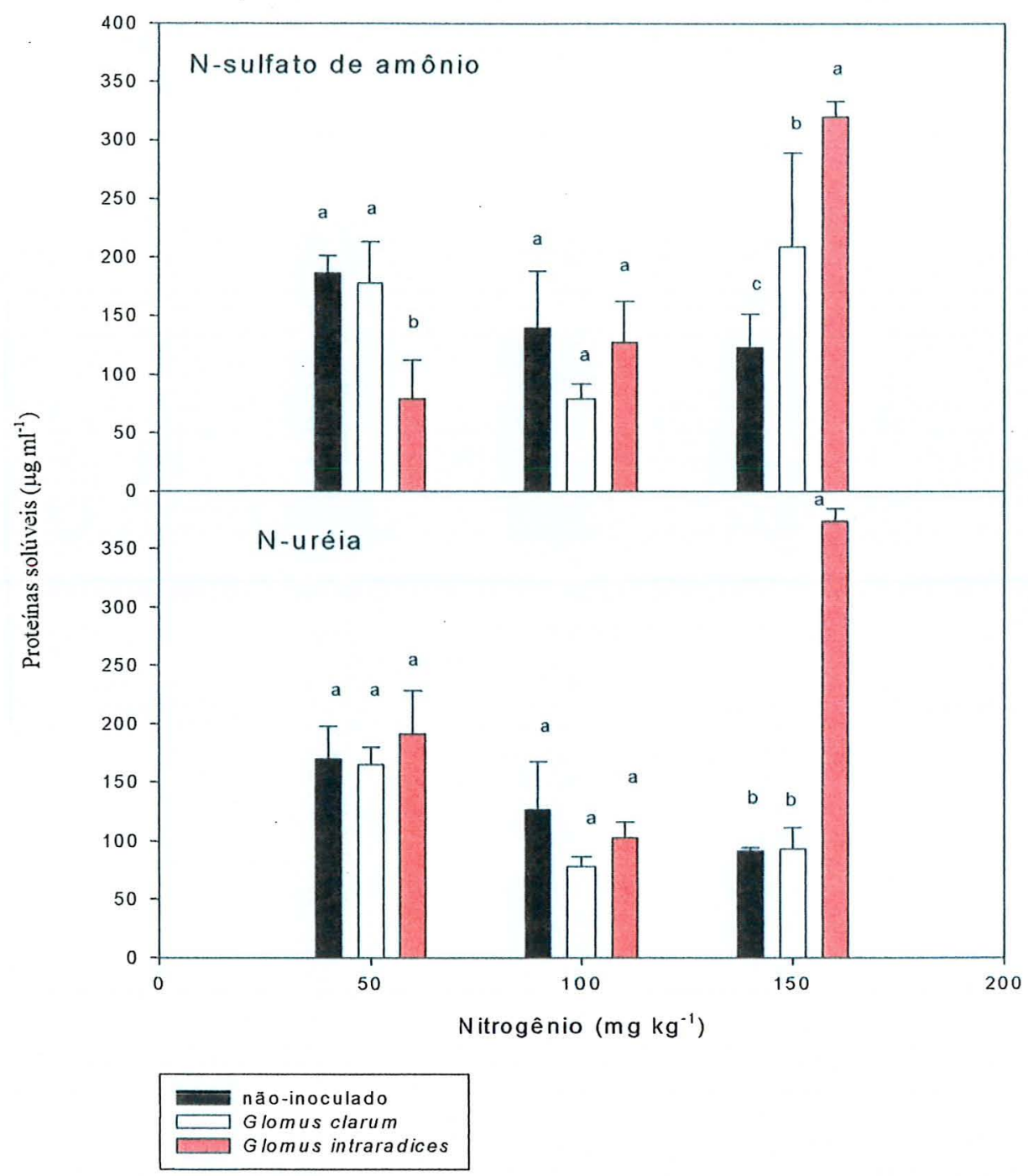

Figura 5 - Concentração de proteínas em extratos de raízes de Nicotiana tabacum cultivada na presença de sulfato de amônio ou uréia como fonte de nitrogênio, e inoculada com fungos micorrízicos arbusculares. Os dados são médias de 4 repetições \pm desvio padrão da média. Médias dos tratamentos de inoculação seguidas por letras iguais não diferem estatisticamente, para mesma dose e fonte de nitrogênio (Tukey, $\mathrm{p}<0,05$ ). 


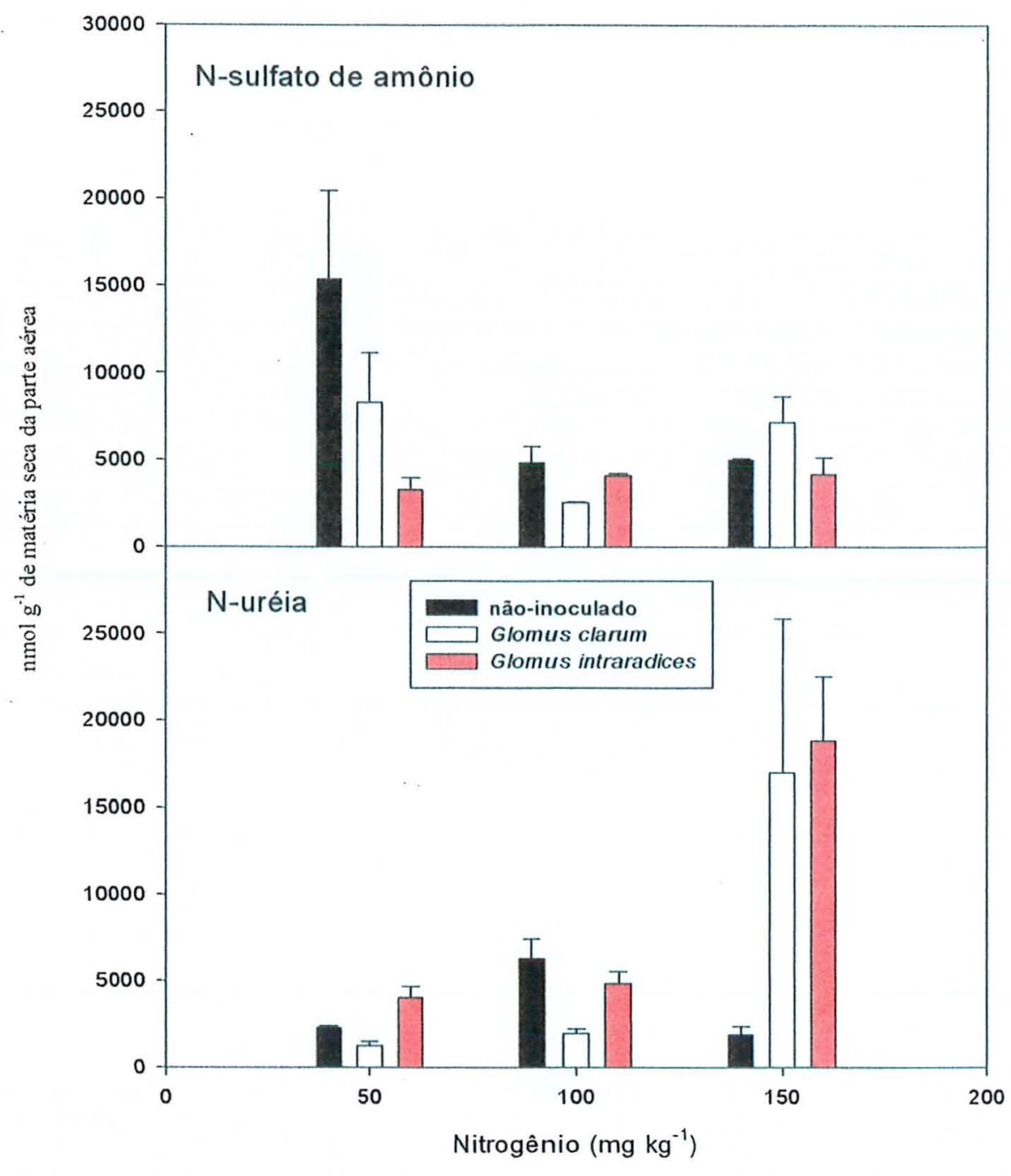

Figura 6 - Concentração de aminoácidos solúveis na parte aérea de Nicotiana tabacum, não-inoculada ou inoculada com G. clarum ou G. intraradices, e cultivada em vasos contendo diferentes concentrações de $\mathrm{N}$ na forma de uréia ou sulfato de amônio. Os dados são médias de 4 repetições \pm desvio padrão da média. 
intraradices causou diminuição do teor de aminoácidos solúveis na parte aérea.Nas demais concentrações de $\mathrm{N}$-sulfato de amônio, diferenças significativas entre os tratamentos inoculados e não inoculado não foram observadas (Tukey, $\mathrm{p}<0,05$ ).

Em plantas cultivadas com $150 \mathrm{mg} \mathrm{kg}^{-1}$ de $\mathrm{N}$-uréia, a inoculação com $G$. clarum e $G$. intraradices induziu aumentos de aproximadamente 10 vezes na concentração de aminoácidos solúveis, em relação aos controles não-inoculados (Figura 6). Os resultados obtidos sugerem que em baixas concentrações de $N$, na forma de sulfato de amônio, a translocação de aminoácidos para as raízes é maior em plantas micorrizadas.

Plantas de soja inoculadas com G. fasciculatum também apresentaram menores teores de aminoácidos solúveis nas folhas, em relação a plantas não-inoculadas, quando adubadas com $\mathrm{NH}_{4} \mathrm{NO}_{3}$. Mas, quando utilizou-se fixação biológica de $\mathrm{N}$ por Bradyrhizobium, como fonte de $\mathrm{N}$ para as plantas, a inoculação com $G$. fasciculatum resultou em aumentos significativos do teor de aminoácidos solúveis na parte aérea (Pacovsky, 1989).

Em centeio, foi observado que a inoculação com $G$. fasciculatum resulta em aumentos da concentração de aminoácidos, em relação ao controle não-inoculado (Faure et al., 1998). Em plantas de milho colonizadas por Glomus intraradices os teores de aminoácidos foram de 2 a 3 vezes maiores em plantas micorrizadas do que em plantas não-micorrizadas (Subramanian \& Charest, 1998). Já, em plantas de milho, sob estresse hídrico, o teor total de aminoácidos solúveis não foi alterado pela inoculação com $G$. mosseae (Schellenbaum et al., 1998). Da mesma forma, morangueiros micorrizados cultivados in vitro, e que sofreram estresse hídrico induzido por polietileno glicol, não apresentaram diferenças significativas no acúmulo de aminoácidos solúveis na parte aérea e no sistema radicular, em relação ao controle não-inoculado (Hernández-Sebastiá et al., 2000).

Tem sido observado também que plantas de arroz adubadas com uréia apresentam maiores teores de aminoácidos solúveis, quando comparado com plantas adubadas com $\mathrm{NH}_{4} \mathrm{NO}_{3}$ (Gerendas et al., 1998). Em Ricinus communis, o teor de aminoácidos na seiva do xilema é maior em plantas cultivadas na presença de $\mathrm{NH}_{4}{ }^{+}$do 
que em plantas cultivadas com $\mathrm{NO}_{3}^{-}$. Da mesma forma, o teor de aminoácidos na seiva das folhas é 12 vezes maior nas plantas cultivadas com $\mathrm{NH}_{4}{ }^{+}$, quando comparados com as plantas cultivadas com $\mathrm{NO}_{3}{ }^{-}$(Allen \& Smith, 1986).

No presente experimento, embora o $\mathrm{N}$ esteja, provavelmente, sendo absorvido predominantemente na forma de $\mathrm{NH}_{4}{ }^{+}$, a presença do fungo micorrízico pode estar interferindo no processo de translocação de aminoácidos para as raízes, já que as concentrações de $\mathrm{N}$ na parte aérea de plantas micorrizadas e não-micorrizadas não diferem estatisticamente, independentemente da fonte ou dose de $\mathrm{N}$ (Figura 7). Maior translocação de aminoácidos para as raizes pode também estar ocorrendo em plantas cultivadas com uréia, principalmente na menor concentração.

Os perfis de aminoácidos dos diferentes tratamentos podem ser vistos nas Figuras 8 e 9 . A abundância relativa média dos aminoácidos solúveis apresentou-se da seguinte maneira: glutamina (32,65\%), ácido $\gamma$-amino butírico $(11,89 \%)$, asparagina $(11,22 \%)$, glutamato $(9,05 \%)$, lisina $(8,45 \%)$, alanina $(5,46 \%)$, serina $(5,20 \%)$, treonina $(4,45 \%)$, valina $(3,47 \%)$, metionina $(1,87 \%)$, aspartato $(1,53 \%)$, fenilalanina $(1,49 \%)$, leucina $(1,46 \%)$, tirosina $(0,91 \%)$, isoleucina $(0,70 \%)$, histidina $(0,15 \%)$, arginina $(0,04 \%)$ e glicina $(<0,01 \%)$.

A glutamina (GLN) foi o aminoácido mais abundante nas plantas de tabaco, e sua concentração não foi influenciada pelos tratamentos (Tabela 2). A GLN também foi o aminoácido mais abundante em Pittosporum toriba, e sua concentração não foi afetada pela inoculação com $G$. mosseae, quando as plantas foram adubadas com $\mathrm{NH}_{4}{ }^{+}$ (Coxwell \& Johnson, 1985). Em contraste, em milho a concentração de GLN nas folhas aumentou significativamente em plantas inoculadas com $G$. intraradices e adubadas com solução de Hoagland completa (Subramanian \& Charest, 1998).

A concentração de ácido $\gamma$-aminobutírico (GABA) foi significativamente afetada pelas interações dos fatores "FONTES DE N" * "DOSES DE N" e "FONTES DE N" e "FUNGO MICORRÍZICO". Na presença de $150 \mathrm{mg} \mathrm{kg}^{-1} \mathrm{~N}$-uréia, as concentrações de GABA na parte aérea de plantas micorrizadas foi significativamente superior aos controles não-inoculados (Figura 8). 


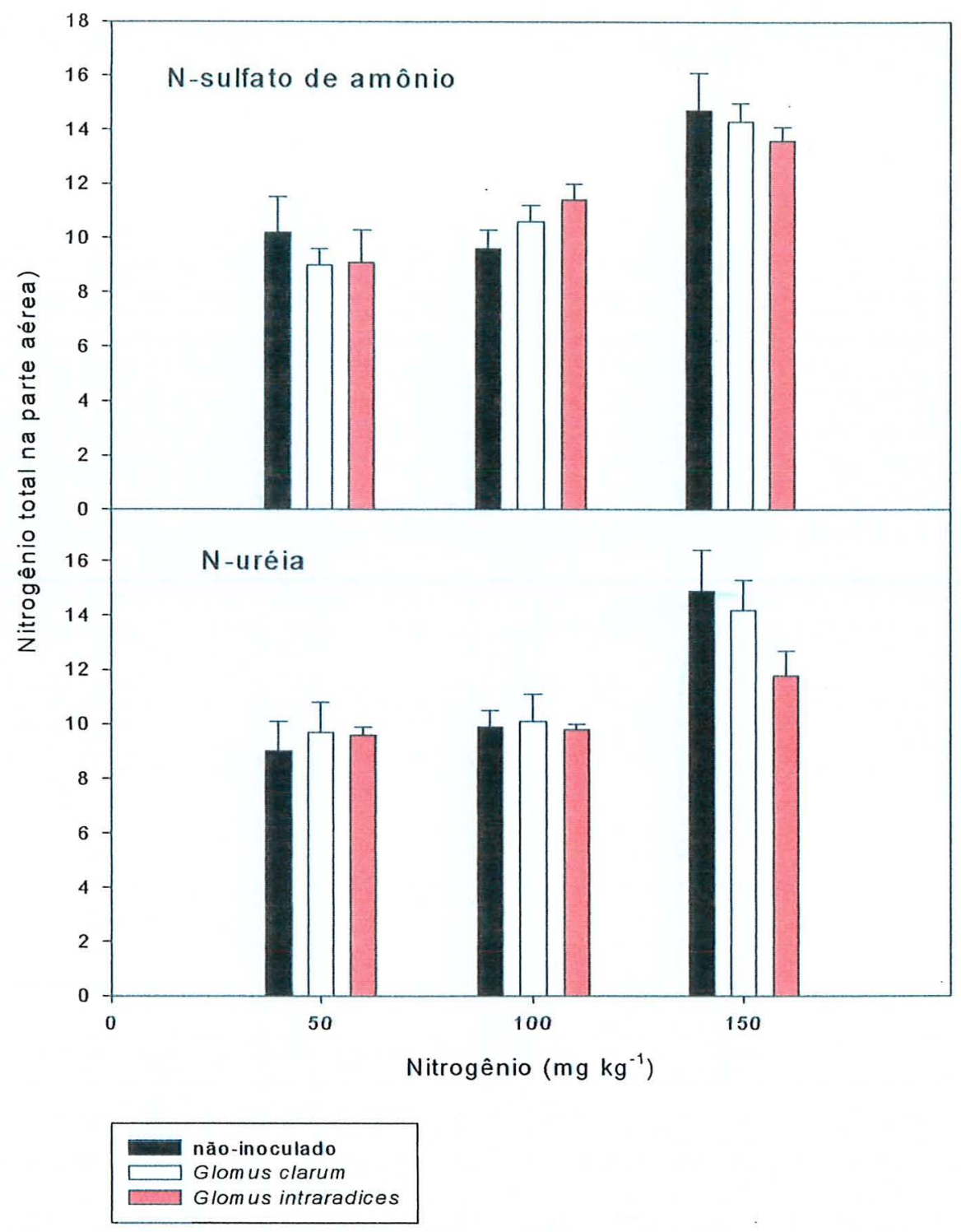

Figura 7 - Concentração de nitrogênio na parte aérea de Nicotiana tabacum, nãoinoculada ou inoculada com os fungos G. clarum ou G. intraradices, e cultivada em vasos contendo diferentes concentrações de nitrogênio na forma de uréia ou sulfato de amônio. Os dados são médias de 4 repetições \pm desvio padrão da média. 


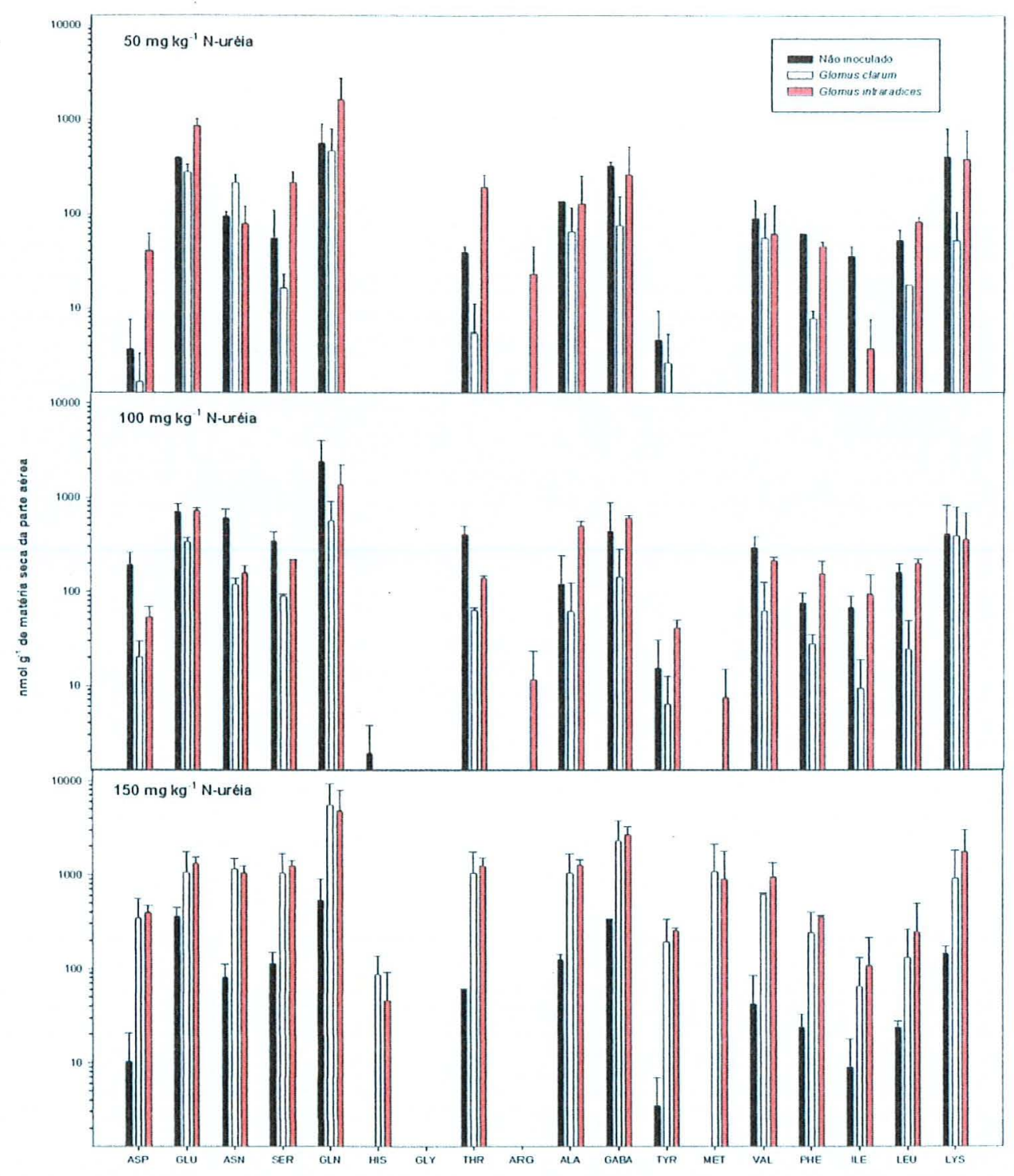

Figura 8 - Perfis de aminoácidos solúveis na parte aérea de Nicotiana tabacum, nãoinoculada ou inoculada com os fungos G. clarum ou G. intraradices, e cultivada em vasos contendo diferentes concentrações de nitrogênio na forma de uréia. Os dados são médias de duas repetições \pm desvio padrão da média. 


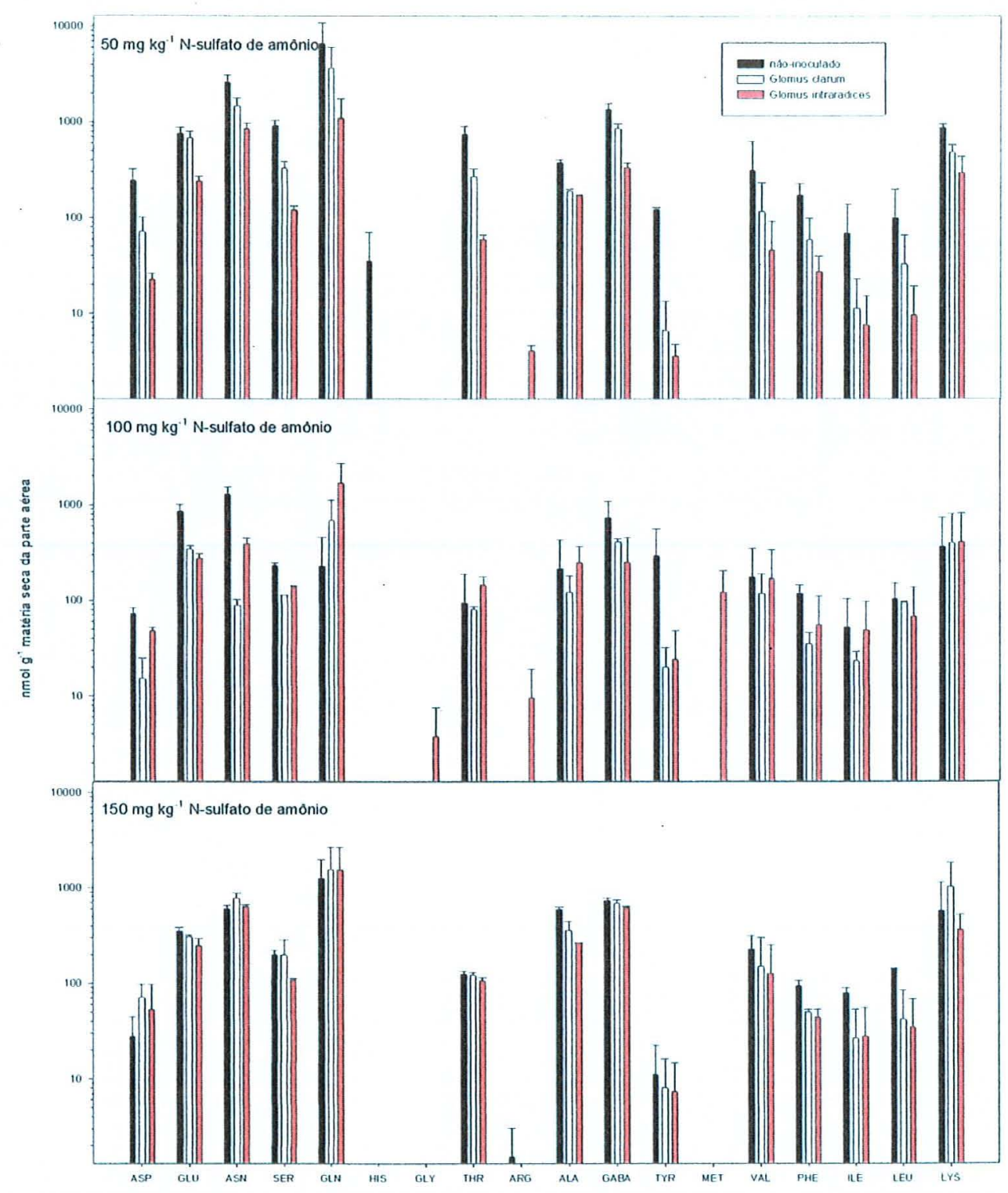

Figura 9 - Perfis de aminoácidos solúveis na parte aérea de Nicotiana tabacum, nãoinoculada ou inoculada com os fungos G. clarum ou G. intraradices, e cultivada em vasos contendo diferentes concentrações de Nitrogênio na forma de sulfato de amônio. Os dados são médias de duas repetições \pm . desvio padrão da média. 
Tabela 2 - Níveis de significância da análise de variância para as concentrações de aminoácidos solúveis na parte aérea de Nicotiana tabacum.

\begin{tabular}{|c|c|c|c|c|c|c|c|}
\hline \multirow[b]{2}{*}{ Aminoácido } & \multicolumn{7}{|c|}{ Fontes de variação } \\
\hline & $F$ & D & $\mathrm{M}$ & FxD & $\mathrm{FxM}$ & DxM & FxDxM \\
\hline ASP & ns & $*$ & $\mathrm{~ns}$ & $* *$ & ns & $* *$ & ns \\
\hline GLU & $*$ & $\mathrm{~ns}$ & ns & $*$ & $* *$ & ns & ns \\
\hline ASN & $* * *$ & $* *$ & $*$ & $* * *$ & $* * *$ & $* * *$ & ns \\
\hline SER & ns & $* *$ & ns & $* * *$ & $* *$ & $* *$ & ns \\
\hline GLN & ns & ns & ns & ns & ns & ns & ns \\
\hline HIS & ns & ns & ns & $*$ & ns & ns & ns \\
\hline GLY & ns & ns & $\mathrm{ns}$ & ns & ns & ns & ns \\
\hline THR & ns & $*$ & ns & $* *$ & ns & $*$ & ns \\
\hline $\mathrm{ARG}$ & ns & ns & ns & $\mathrm{ns}$ & ns & ns & ns \\
\hline ALA & $* * *$ & ns & ns & ns & $*$ & ns & ns \\
\hline GABA & ns & $* *$ & ns & $* *$ & * & ns & ns \\
\hline TYR & ns & ns & ns & $*$ & $*$ & ns & ns \\
\hline MET & ns & ns & ns & ns & ns & ns & ns \\
\hline VAL & ns & $*$ & ns & ns & ns & ns & ns \\
\hline PHE & ns & $*$ & ns & $* *$ & $* *$ & $*$ & ns \\
\hline ILE & ns & ns & ns & ns & ns & ns & ns \\
\hline LEU & ns & ns & ns & ns & ns & ns & ns \\
\hline LYS & ns & ns & ns & ns & ns & ns & ns \\
\hline Total & ns & $*$ & ns & $* *$ & $*$ & $*$ & ns \\
\hline
\end{tabular}


Asparagina (ASN) e Serina (SER) foram os aminoácidos mais afetados pelos tratamentos (Tabela 2). No geral, suas concentrações foram mais elevadas em plantas cultivadas com $50 \mathrm{mg} \mathrm{kg}^{-1} \mathrm{~N}$-sulfato de amônio (Figura 9). Aumentos significativos da concentração de ASN e SER em plantas micorrizadas em relação a plantas nãomicorrizadas, foram observados na presença de $150 \mathrm{mg} \mathrm{kg}^{-1} \mathrm{~N}$-uréia (Figura 9).

A concentração de glutamato (GLU) foi significativamente afetada pelas interações dos fatores "FONTES DE N" * "DOSES DE N", e "FONTES DE N" e "FUNGOS MICORRÍZICOS" (Tabela 2). No geral, as concentrações de GLU na parte aérea de plantas inoculadas com FMAs foram maiores, em relação aos controles nãoinoculados, com $150 \mathrm{mg} \mathrm{N} \mathrm{kg}^{-1}$. Com 50 e $100 \mathrm{mg} \mathrm{kg}^{-1} \mathrm{~N}$-sulfato de amônio, as concentrações de GLU foram menores nas plantas inoculadas com G. clarum ou $G$. intraradices, comparado com os controles não-inoculados (Figura 9).

A concentração de alanina (ALA) foi significativamente afetada pela interação entre os fatores "FONTES DE N" e "FUNGOS MICORRÍZICOS". Em plantas cultivadas com N-uréia, a inoculação com FMAs induziu aumentos significativos da concentração de ALA na parte aérea (Figura 8). No entanto, em plantas cultivadas com $\mathrm{N}$-sulfato de amônio, a inoculação com FMAs induziu decréscimos significativos na concentração de ALA na parte aérea (Figura 9).

A concentração de treonina (THR) foi significativamente afetada pela interação dos fatores "FONTES DE $\mathrm{N}$ " * "DOSES DE $\mathrm{N}$ ” * "FUNGOS MICORRÍZICOS" (Tabela 2). Aumentos significativos na concentração de THR na parte aérea de plantas micorrizadas foram observadas com $150 \mathrm{mg} \mathrm{kg}^{-1} \mathrm{~N}$-uréia, em relação aos controles não-inoculados (Figura 8). Na presença de $50 \mathrm{mg} \mathrm{kg}^{-1} \mathrm{~N}$-sulfato de amônio, as concentrações de THR na parte aérea de plantas micorrizadas foram menores do que nos controles não-inoculados (Figura 9).

A concentração de valina (VAL) só foi significativamente afetada pela dose de $N$ (Tabela 2). No geral, sua concentração aumentou com o aumento das concentrações de $\mathrm{N}$ adicionado (Figuras 8 e 9).

A concentração de aspartato (ASP) foi significativamente afetada pela interação dos fatores "FONTES DE N" * "DOSES DE N" e "DOSES DE N" * 
"FUNGOS MICORRÍZICOS". No geral, as maiores concentrações de ASP foram observadas em plantas inoculadas, na presença de $150 \mathrm{mg} \mathrm{kg}^{-1} \mathrm{~N}$-uréia (Figura 8).

A concentração de fenilalanina (PHE) foi significativamente afetada pelas interações dos fatores "FONTES DE $\mathrm{N}$ " * 'DOSES DE N", "FONTES DE N" * "FUNGOS MICORRÍZICOS" e "DOSES DE N" * "FUNGOS MICORRÍZICOS" (Tabela 2). Em plantas inoculadas com G. clarum e com $50 \mathrm{mg} \mathrm{kg}^{-1}$ a concentração de PHE foi menor do que no controle não-inoculado (Figura 8). Já, com $150 \mathrm{mg} \mathrm{kg}^{-1} \mathrm{~N}$ uréia, os tratamentos inoculados com FMAs apresentaram concentrações mais elevadas de PHE do que o controle não-inoculado (Figura 8). Na presença de $50 \mathrm{mg} \mathrm{kg}^{-1} \mathrm{~N}$ sulfato de amônio, a concentração de PHE na parte aérea das plantas inoculadas por G.clarum ou G. intraradices foi menor do que no controle não-inoculado (Figura 9).

A concentração de tirosina (TYR) foi significativamente afetada pelas interações dos fatores "FONTES DE N" * "DOSES DE N" e "FONTES DE N" * "FUNGOS MICORRÍZICOS". Com $150 \mathrm{mg} \mathrm{kg}^{-1} \mathrm{~N}$-uréia, a concentração de TYR na parte aérea das plantas inoculadas com $G$. clarum ou $G$. intraradices foi, respectivamente, 55 e 73 vezes maior do que no controle não-inoculado (Figura 8). Já, com 50 ou $100 \mathrm{mg} \mathrm{kg}^{-1} \mathrm{~N}$-sulfato de amônio, as concentrações de TYR foram aproximadamente 23 e 13 vezes menores, respectivamente, do que no controle nãoinoculado (Figura 9).

Para determinar se as atividades de ureases estavam relacionadas com alterações nos perfis de aminoácidos, foi feita uma análise de correlação múltipla. Os resultados indicam que as atividades de ureases não estão correlacionadas com a concentração de nenhum dos aminoácidos analisados $(p<0,05)$.

\subsection{Nutrientes na parte aérea}

Os resultados da análise de variância das concentrações de macro e micro nutrientes na parte aérea de tabaco nos diferentes tratamentos podem ser vistas na Tabela 3. As concentrações de nutrientes na parte aérea de tabaco nos diferentes tratamentos são apresentadas nas Tabelas 4 e 5. Pode-se observar que a concentração de N na parte aérea 
Tabela 3 - Níveis de significância da análise de variância para os teores de macro e micronutrientes na parte aérea de Nicotiana tabacum.

\begin{tabular}{|c|c|c|c|c|c|c|c|}
\hline \multirow[b]{2}{*}{ Nutriente } & \multicolumn{7}{|c|}{ Fontes de variação } \\
\hline & $\mathrm{F}$ & $\mathrm{D}$ & $\mathrm{M}$ & FxD & FxM & DxM & FxDxM \\
\hline Nitrogênio & ns & $* * *$ & ns & ns & ns & ns & $\mathrm{ns}$ \\
\hline Fósforo & $*$ & $* * *$ & $* *$ & $*$ & ns & $*$ & $*$ \\
\hline Potássio & $* * *$ & $* * *$ & ns & ns & ns & ns & ns \\
\hline Cálcio & $* * *$ & $* * *$ & ns & ns & ns & ns & ns \\
\hline Magnésio & $* * *$ & $*$ & ns & ns & ns & ns & ns \\
\hline Enxofre & $* * *$ & $* * *$ & ns & $* * *$ & ns & ns & ns \\
\hline Boro & $* *$ & $* *$ & ns & ns & ** & ns & ns \\
\hline Cobre & $* * *$ & $* * *$ & $* *$ & $* * *$ & ns & ns & $*$ \\
\hline Ferro & ns & ns & ns & ns & ns & ns & ns \\
\hline Manganês & $*$ & $* * *$ & $*$ & $*$ & ns & $*$ & ns \\
\hline Zinco & $* * *$ & $* * *$ & $*$ & $*$ & ns & ns & ns \\
\hline
\end{tabular}


Tabela 4 - Concentração de macronutrientes na parte aérea de Nicotiana tabacum, nãoinoculada ou inoculada com os fungos $G$. clarum ou $G$. intraradices, e cultivada em vasos contendo diferentes concentrações de Nitrogênio na forma de uréia ou sulfato de amônio.

\begin{tabular}{lccccc}
\hline Tratamentos & \multicolumn{5}{c}{ Nutrientes $\left(\mathrm{g} \mathrm{kg}^{-1}\right)$} \\
& $\mathrm{P}$ & $\mathrm{K}$ & $\mathrm{Ca}$ & $\mathrm{Mg}$ & $\mathrm{S}$ \\
\hline Ni 50 UR & $3,4 \pm 0,3$ & $24,4 \pm 1,0$ & $10,9 \pm 1,0$ & $10,6 \pm 0,7$ & $2,4 \pm 0,2$ \\
Ni 100 UR & $3,2 \pm 0,3$ & $24,2 \pm 1,3$ & $8,7 \pm 0,7$ & $7,7 \pm 0,2$ & $1,9 \pm 0,1$ \\
Ni 150 UR & $2,5 \pm 0,1$ & $19,7 \pm 1,4$ & $7,4 \pm 1,0$ & $8,7 \pm 1,0$ & $2,1 \pm 0,1$ \\
Gc 50 UR & $4,2 \pm 0,6$ & $29,9 \pm 6,1$ & $11,4 \pm 2,0$ & $11,3 \pm 2,0$ & $2,7 \pm 0,6$ \\
Gc 100 UR & $2,8 \pm 0,3$ & $20,5 \pm 0,6$ & $8,0 \pm 0,2$ & $9,7 \pm 0,3$ & $2,2 \pm 0,2$ \\
Gc 150 UR & $1,9 \pm 0,4$ & $17,05 \pm 1,9$ & $6,3 \pm 0,1$ & $8,2 \pm 0,3$ & $2,1 \pm 0,3$ \\
Gi 50 UR & $2,4 \pm 0,2$ & $22,0 \pm 0,8$ & $8,5 \pm 0,9$ & $8,8 \pm 0,7$ & $2,2 \pm 0,1$ \\
Gi 100 UR & $2,7 \pm 0,1$ & $24,6 \pm 1,3$ & $8,4 \pm 0,5$ & $8,9 \pm 0,9$ & $2,2 \pm 0,1$ \\
Gi 150 UR & $2,1 \pm 0,1$ & $18,7 \pm 1,0$ & $6,0 \pm 0,6$ & $8,3 \pm 0,5$ & $2,1 \pm 0,2$ \\
Ni 50 SA & $4,3 \pm 0,4$ & $27,5 \pm 1,7$ & $6,5 \pm 0,5$ & $7,9 \pm 0,9$ & $3,0 \pm 0,7$ \\
Ni 100 SA & $2,5 \pm 0,1$ & $21,5 \pm 1,8$ & $4,5 \pm 0,4$ & $6,6 \pm 0,3$ & $2,6 \pm 0,3$ \\
Ni 150 SA & $2,9 \pm 0,3$ & $25,0 \pm 1,4$ & $4,2 \pm 0,3$ & $8,0 \pm 0,9$ & $4,9 \pm 0,8$ \\
Gc 50 SA & $3,9 \pm 0,1$ & $29,0 \pm 0,5$ & $5,7 \pm 0,3$ & $7,3 \pm 0,7$ & $2,5 \pm 0,3$ \\
Gc 100 SA & $2,7 \pm 0,1$ & $25,3 \pm 0,7$ & $4,0 \pm 0,3$ & $6,5 \pm 0,4$ & $3,0 \pm 0,4$ \\
Gc 150 SA & $2,9 \pm 0,1$ & $24,6 \pm 1,7$ & $4,2 \pm 0,4$ & $7,1 \pm 0,2$ & $4,9 \pm 0,2$ \\
Gi 50 SA & $3,4 \pm 0,1$ & $28,9 \pm 2,0$ & $5,2 \pm 0,4$ & $7,1 \pm 0,9$ & $2,5 \pm 0,2$ \\
Gi 100 SA & $2,8 \pm 0,1$ & $25,2 \pm 0,7$ & $4,9 \pm 0,2$ & $6,9 \pm 0,4$ & $3,2 \pm 0,3$ \\
Gi 150 SA & $2,5 \pm 0,2$ & $23,4 \pm 1,0$ & $3,5 \pm 0,3$ & $5,7 \pm 0,4$ & $3,5 \pm 0,4$ \\
\hline
\end{tabular}

Os dados são médias de 4 repetições \pm desvi padrão da média. 
Tabela 5 - Concentração de micronutrientes na parte aérea de Nicotiana tabacum, nãoinoculada ou inoculada com os fungos $G$. clarum ou $G$. intraradices, e cultivada em vasos contendo diferentes concentrações de Nitrogênio na forma de uréia ou sulfato de amônio.

\begin{tabular}{lccccc}
\hline Tratamentos & \multicolumn{5}{c}{ Nutrientes } \\
& $\mathrm{B}$ & $\mathrm{Cu}$ & $\mathrm{Fe}$ & $\mathrm{Mn}$ & $\mathrm{Zn}$ \\
\hline $\mathrm{Ni}$ 50 UR & $74,5 \pm 6,5$ & $23,8 \pm 1,7$ & $668,3 \pm 204,7$ & $215,0 \pm 25,9$ & $49,3 \pm 7,8$ \\
$\mathrm{Ni}$ 100 UR & $47,3 \pm 5,9$ & $15,3 \pm 0,9$ & $323,3 \pm 85,2$ & $139,3 \pm 7,9$ & $29,8 \pm 1,3$ \\
$\mathrm{Ni}$ 150 UR & $49,8 \pm 7,4$ & $13,8 \pm 1,0$ & $326,5 \pm 117,2$ & $128,8 \pm 11,9$ & $27,8 \pm 1,4$ \\
Gc 50 UR & $65,5 \pm 2,5$ & $27,5 \pm 2,5$ & $476,5 \pm 37,6$ & $195,5 \pm 26,3$ & $46,0 \pm 8,7$ \\
Gc 100 UR & $68,0 \pm 3,6$ & $14,5 \pm 1,3$ & $387,8 \pm 190,0$ & $154,0 \pm 6,0$ & $32,8 \pm 2,7$ \\
Gc 150 UR & $62,0 \pm 3,9$ & $14,8 \pm 1,2$ & $177,8 \pm 23,4$ & $119,0 \pm 11,8$ & $33,3 \pm 4,6$ \\
Gi 50 UR & $61,8 \pm 5,4$ & $17,5 \pm 4,2$ & $347,5 \pm 138,0$ & $141,5 \pm 8,1$ & $31,5 \pm 2,8$ \\
Gi 100 UR & $59,8 \pm 11,5$ & $16,5 \pm 1,0$ & $191,0 \pm 18,9$ & $128,5 \pm 15,3$ & $30,8 \pm 0,9$ \\
Gi 150 UR & $50,8 \pm 2,5$ & $10,8 \pm 0,6$ & $322,3 \pm 65,4$ & $114,8 \pm 7,2$ & $27,0 \pm 2,6$ \\
Ni 50 SA & $94,0 \pm 12,5$ & $16,3 \pm 1,8$ & $503,8 \pm 185,0$ & $196,8 \pm 24,0$ & $31,0 \pm 3,6$ \\
Ni 100 SA & $65,7 \pm 6,7$ & $13,3 \pm 0,7$ & $772,0 \pm 522,7$ & $154,0 \pm 17,2$ & $25,0 \pm 2,0$ \\
Ni 150 SA & $87,0 \pm 8,7$ & $15,3 \pm 0,9$ & $481,0 \pm 217,8$ & $153,8 \pm 8,8$ & $26,8 \pm 1,9$ \\
Gc 50 SA & $75,8 \pm 9,6$ & $12,5 \pm 1,0$ & $534,8 \pm 273,8$ & $181,3 \pm 15,2$ & $31,3 \pm 3,7$ \\
Gc 100 SA & $54,8 \pm 4,3$ & $15,8 \pm 1,8$ & $357,5 \pm 67,5$ & $156,5 \pm 16,1$ & $27,0 \pm 2,4$ \\
Gc 150 SA & $52,5 \pm 4,8$ & $17,0 \pm 1,4$ & $331,3 \pm 124,9$ & $168,3 \pm 8,8$ & $27,5 \pm 0,3$ \\
Gi 50 SA & $73,3 \pm 8,7$ & $11,5 \pm 0,6$ & $651,3 \pm 374,7$ & $146,3 \pm 9,9$ & $23,5 \pm 1,2$ \\
Gi 100 SA & $70,0 \pm 9,0$ & $12,3 \pm 0,9$ & $276,8 \pm 98,0$ & $172,3 \pm 13,2$ & $24,8 \pm 2,6$ \\
Gi 150 SA & $59,8 \pm 6,9$ & $16,0 \pm 1,1$ & $270,5 \pm 83,4$ & $148,0 \pm 18,6$ & $24,3 \pm 1,7$ \\
\hline Os
\end{tabular}

Os dados são médias de 4 repetições \pm desvi padrão da média. 
está diretamente relacionada com a concentração de $\mathrm{N}$ aplicado ao substrato, independentemente da fonte de $\mathrm{N}$ (Figura 7). Já, as concentrações de P, K, Ca, B, e Mn diminuiram com o aumento da concentração de $\mathrm{N}$.

A interação dos fatores "DOSES DE N" * "FONTES DE N"* "FUNGOS MICORRÍZICOS" teve efeito significativo sobre a concentração de $\mathrm{P}$ na parte aérea $(\mathrm{p}<0,05)$. As concentrações de $\mathrm{P}$ na parte aérea de plantas não-inoculadas ou inoculadas com G. clarum não apresentaram diferenças significativas entre si $(\mathrm{p}<0,05)$. No entanto, plantas inoculadas com $G$. intraradices apresentaram menor concentração de $\mathrm{P}$ na parte aérea, comparado com o controle não-inoculado. $O$ aumento da concentração de $P$ na parte aérea de plantas micorrizadas pode ter efeito sobre a atividade das enzimas enzimas envolvidas na assimilação do N. Oliver et al. (1993) reportaram que aumentos na capacidade de trevo micorrizados em sintetizar nitrato-redutase, o que foi atribuído a um efeito indireto associado com a melhoria da nutrição de $\mathrm{P}$ da planta hospedeira. $\mathrm{O}$ aumento da concentração de $\mathrm{P}$ nas plantas, devido a associação micorrízica, pode facilitar também reações enzimáticas dependentes de ATP, especialmente a catalizada pela glutamina-sintetase (Lea et al., 1990).

As plantas cultivadas com $\mathrm{N}$-sulfato de amônio apresentaram maiores teores de $S$, quando comparadas com plantas que receberam $N$-uréia $(p<0,05)$, o que pode ser explicado pelo fato do sulfato de amônio ser também uma fonte de $S$.

As concentrações de $\mathrm{Cu}$ e $\mathrm{Zn}$ na parte aérea de plantas cultivadas com $\mathrm{N}$-sulfato de amônio foram menores do que em plantas cultivadas com N-uréia. Esta menor absorção de nutrientes metálicos concorda com as observações de Gerendas et al. (1997), e pode ser a explicação para o menor crescimento de tabaco cultivado em Nsulfato de amônio, quando comparado com $\mathrm{N}$-uréia. 


\section{CONCLUSÕES}

As atividades de ureases apresentaram correlação positiva com a colonização intraradicular nos tratamentos com $50 \mathrm{mg} \mathrm{kg}^{-1} \mathrm{~N}$-sulfato de amônio, sugerindo que em condições de baixo $\mathrm{N}$ no solo, ureases podem estar envolvidas no controle da colonização radicular.

As atividades de urease não apresentaram correlação com a concentração total de aminoácidos solúveis na parte aérea.

Alterações nos perfis de aminoácidos na parte aérea de plantas micorrizadas, em relação aos controles não-inoculados, também foram observados.

Os dados obtidos neste trabalho sugerem que as atividades de ureases nas raízes, em condições de baixo $\mathrm{N}$, podem estar realacionadas com a capacidade de colonização intrarradicular dos fungos, e que fungos micorrízicos podem alterar o metabolismo de $\mathrm{N}$ nas plantas. 


\section{REFERÊNCIAS BIBLIOGRÁFICAS}

ALEXANDER, T.; MEIER, R.; TOTH, R.; WEBER, H.C. Dynamics of arbuscule development and degeneration in mycorrhizas of Triticum aestivum L. and Avena sativa L. with reference to Zea mays L. New Phytologist, v. 110, n.3, p.363-370, 1988.

ALEXANDER, T.; TOTH, R.; MEIER, R.; WEBER, H.C. Dynamics of arbuscule development and degeneration in onion, bean and tomato with reference to vesicular arbuscular mycorrhizae in grasses. Canadian Journal of Botany, v.67, n.8, p. 2505-2513, 1989.

ALLEN, M.F.; ALLEN, E.B., FRIESE C.F. Responses of the non-mycotrophic plant Solsola kali to invasion by vesicular-arbuscular mycorrhizal fungi. New Phytologist, v.111, n.1, p.45-49, 1989.

ALLEN, S. \& SMITH, J.A.C. Ammonium nutrition in Ricinus communis: its effect on plant growth and the chemical composition of the whole plant, xylem and phloem saps. Journal of Experimental Botany, v.37, n. 184, p.1599-1610, 1986.

AMES, R.N.; REID, C.P.P.; INGHAM, E.R. Rhizosphere bacterial population responses to root colonization by a vesicular arbuscular mycorrhizal fungus. New phytologist, v.96, n.4, p.555-563, 1984.

ARINES, J.; PALMA, J.M.; VILARINO, A. Comparison Of Protein-Patterns In Nonmycorrhizal And Vesicular-Arbuscular Mycorrhizal Roots Of Red-Clover. New Phytologist, v. 123, n.4, p. 763-768, 1993.

AZCÓN, R.; GOMEZ, M.; TOBAR R. Effects of nitrogen source on growth, nutrition, photosynthetic rate and nitrogen metabolism of mycorrhizal and phosphorusfertilized plants of Lactuca sativa L. New Phytologist, n.121, p.227-234, 1992. 
BAGO, B.; CHAMBERLAND, H., GOULET, A.; VIERHEILIG, H.; LAFONTAINE JG.; PICHE, Y. Effect of Nikkomycin Z, a chitin-syntase inhibitor, on hyphal growth and cell wall structure of two arbuscular-mycorrhizal fungi. Protoplasma, v.192, n.1-2, p.80-92,1996.

BECARD G., DOUDS D.D., PFEFFER P.E. Extensive in vitro hyphal growth of vesicular-arbuscular mycorrhizal fungi in the presence of $\mathrm{CO}_{2}$ and flavonols. Applied Environmental Microbiology, v.58, n.3, p.821-825, 1992.

BECARD, G.; TAYLOR, L.P.; DOUDS, D.D. et al. Flavonoids are not necessary plant signal compounds in arbuscular mycorrhizal simbiosis. Molecular Plant-Microbe Interections, v.8, n.2, p. 252-258, 1995.

BEEVER, R. E.; BURNS, D.J. Phosphorus upatke storage and utilization by fungi. Advances in botanic research, v. 8, n. 1, 128-219, 1980.

BIELESKI, R.L.; TURNER, N.A. Separation and estimation of amino acids in crude plant extracts by thin-layer electrophoresis and chromatography. Analytical Biochemestry, v.17, n.2, p.278-293, 1966.

BLILOU, I.; OCAMPO, J.A.; GARCIAA-GARRIDO, J.M. Induction of Ltp (lipid transfer protein) and $\mathrm{Pal}$ (phenylalanine amnonia-lyase) gene expression in rice roots colonized by the arbuscular mycorrhizal fungus Glomus mosseae. Journal of Experimental Botany, v.51, n. 353, p. 1969-1977, Dec 2000.

BODKER, L.; KJOLLER, R.; ROSENDAHL, S. Effect of phosphate and the arbuscular mycorrhizal fungus Glomus intraradices on disease severity of root rot of peas (Pisum sativum) caused by Aphanomyces euteiches. Mycorrhiza, v.8, n.3, p. 169174, 1998.

BONFANTE-FASOLO, P. Anatomy and morphology of VA mycorrhizae. In VA mycorrhizae, ed. CL Powell, DJ Bagyaraj, p.5-33. Boca Raton, FL: CRC Press, 1984.

BONFANTE-FASOLO, P.; PEROTTO, S. Mycorrhizal and pathogenic fungi: Do they share any features? In Electron Microscopy Applied in Plant Pathology, ed. K Mendgen, DE Lesemann, p. 265-75. Berlin: SpringerVerlag, 1990. 
BONFANTE-FASOLO, P.; PEROTTO, S. Plant and endomycorrhizal fungi: the cellular and molecular basis of their interaction. In Molecular Signals in Plant-Microbe Communications, ed. DPS Verma, p. 445-70. Boca Raton, FL: CRC Press, 1992. BONFANTE-FASOLO, P.; PEROTTO, S. Strategies of arbuscular mycorrhizal fungi when infecting host plants. New Phytologist, v.130, n.1, p.3-21, 1995.

BRADBURY, S.M.; PETERSON, R.L.; BOWLEY, S.R. Interaction between three alfalfa nodulation genotypes and two Glomus species. New Phytologist, v.119, n.1, p.115-120, 1991.

BRADFORD, M.M. A rapid and sensitive method for the quantitation of microgram quanties of protein utilizing the principle of protein-dye binding. Analitical Biochemistry, v.72, n.1-2, p.248-254, 1976.

BURLEIGH, S.H.; HARRISON , M.J. A novel gene whose expression in Medicago truncatula roots is suppressed in response to colonization by vesicular-arbuscular mycorrhizal (VAM) fungi and to phosphate nutrition. Plant Molecular Biology, v.34, n.2, p.199-208, 1997.

CARDOSO, E.J.B.N.; LAMBAIS, M.R. Aplicações práticas de micorrizas vesículoarbusculares (MVA). In: CARDOSO, E.J.B.N.; TSAI, S.M.; NEVES, M.C.P. Microbiologia do Solo. Campinas: Sociedade Brasileira de Ciência do Solo, 1992. p.283-296. 1992

CLIQUET, J.B.; MURRAY, P.J.; BOUCAUD, J. Effect of arbuscular mycorrhizal fungus Glomus fasciculatum on the uptake of amino nitrogen by Lolium perenne. New Phytologist, v.137, n.2, p.345-349, 1997.

CLIQUET, J.B.; STEWART, G.R. Ammonia assimilation in Zea mays L. infected with a vesicular-arbuscular mycorrhizal fungus Glomus fasciculatum. Plant Phisiology, v.101, n.3, p.865-871, 1993.

COLE, G.T.; HOWARD, D.H.; MILLER, J.D. Biochemistry of enzymatic pathogenocity factors. The Mycota. A compehensiva treatise on fungi as experimental systems for basic and applied research. Volume VI: Human and animal relationships, p.31-65, 1996. 
COX, G.M.; MUKHERJEE, J.; COLE, G.T. et al. Urease as a virulence factor in experimental cryptococcosis. Infect immunology, v.68, n.2, p.443-448, 2000.

COXWELL, M.A.; JOHNSON, C.R. Effects of vesicular-arbuscular mycorrhizae and nitrogen source on growth and transport amino acid composition of Pittosporum tobira. Journal of American Society Horticultural Science. v.110, n.6, p.800$803,1985$.

CRIPPA, A.; BRUNO, E.; MANGIAROTTI, A.M.; CARETTA, G. Extracelular enzimatic activies of 32 fungal species. Boletin Micologico, v.3, n.2, p.129-134, 1987.

DAVID, R.; ITZHAKI, H.; GINZBERG, I.; GAFNI, Y.; GALILI, G.; KAPULNIK, Y. Suppression of tobacco basic chitinase gene expression in response to colonization by the arbuscular mycorrhizal fungus Glomus intraradices. Molecular plant microbe interactions, v.11, n.6, p.489-497, 1998.

DITT, R.F. Identificação e clonagem molecular de genes com expressão diferencial em raízes de fumo (Nicotiana tabacum) infectadas por Glomus intraradices. Piracicaba, 1997. 98p. Dissertação (Mestrado) - Escola Superior de Agricultura "Luiz de Queiroz", Universidade de São Paulo.

DIXON, N.E.; GAZZOLA, C.; WATTERS, J.J.; BLAKELEY, R.L.; ZERNER, B. Jack bean urease (EC 3.5.1.5). A metalloenzyme. A simple biological role for nickel? Journal of American Chemical Society, v.97, n.14, p.4131-4133, 1975.

DOUDS, D.D.; GALVEZ, L.; BECARD, G., KAPULNIK, Y. Regulation of arbuscular mycorrhizal development by plant host and fungus species in alfalfa. New Phytologist, v.138, n.1, p.27-35, 1998.

DOUDS, D.D.; NAGAHASHI, G.; ABNEY, G.D. The differential effects of cell wallassociated phenolics, cell walls, and cytosolic phenolics of host and non-host roots on the growth of two species of AM fungi. New Phytologist, v.133, n.2, p.289-294, 1996.

DUC, G.; TROUVELOT, A.; GIANINAZZI-PEARSON, V.; GIANINAZZI, S. First report of non-mycorrhizal mutants (myc-) obtained in pea (Pisum sativum L.) and fababean (Vicia faba L.). Plant Science, v.60, n.2, p.215-222, 1989. 
EZETA, F.N.; SANTOS, O. M. Beneficio da introdução de endomicorriza eficiente na utilização de nutrientes em latossolos do sul da Bahia. Revista Brasileira de Ciência do Solo, Campinas, v.9, p.13-17, 1980.

FAURE, S.; CLIQUET J.B.; THEPHANY, G.; et al. Nitrogen assimilation in Lolium perenne colonized by the arbuscular mycorrhizal fungus Glomus fasciculatum, v.138, n.3, p.411-417, 1998.

FREY, B.; SCHUEPP, H. Acquisition of nitrogen by external hyphae of arbuscular mycorrhizal fungi associated with Zea mays L. New Phytologist, v.124, n.2, p. 221-230, 1993.

GARCIA-GARRIDO, J.M.; CABELLO, M.N.; GARCÍA-ROMERA, I.; OCAMPO, J.A. Endoglucanase activity in lettuce plants colonized with the vesiculararbuscular mycorrhizal fungus Glomus fasciculatum. Soil Biology and Biochemistry, v.24, n.10, p.955-959, 1992 a.

GARCIA-GARRIDO, J.M.; GARCIA-ROMERA, I.; OCAMPO, J.A. Cellulase production by the vesicular-arbuscular mycorrhizal fungus Glomus mosseae (Nicol \& Gerd.) Gerd. and Trappe. New Phytologist, v.121, n.2, p.221-226, 1992b.

GERENDAS, J.; ZHU, Z.; SATTELMACHER, B. Influence of $\mathrm{N}$ and $\mathrm{Ni}$ supply on nitrogen metabolism and urease activity in rice. Journal of Experimental Botany, v.49, n.326, p.1545-1554, 1998.

GINZBERG, I.; DAVID, R.; SHAUL, $\mathrm{O}$ et al. Glomus intraradices colonization regulates gene expression in tobacco roots. Symbiosis, v.25, n.1-3, p.145-157, 1998.

GIOVANNETTI, M.; AVIO, L.; SBRANA, C.; CITERNESI, A.S. Factors affecting appressorium development in the vesicular-arbuscular mycorrhizal fungus Glomus mosseae (Nicol. \& Gerd.) Gerd. \& Trappe. New Phytologist, v.123, n.1, p.115122,1993

GIOVANNETTI, M.; MOSSE, B. An evaluation of techniques for measuring vesiculararbuscular mycorrhizal infection in roots. New Phytologist, v.84, n.3, p.489-500, 1980. 
GOLLOTE, A.; GIANINAZZI-PEARSON, V.; GIOVANETTI, M.; et al. Cellular localization and cytochemical probing of resistance reactions to arbuscular mycorrhizal fungi in a 'locus a' myc-mutant of Pisum sativum L. Planta, v.191, n.1, p.112-122, 1993.

HARRISON, M.J. Molecular and celular aspects of arbuscular mycorrhizae. Annual Review of Plant Physiology and Plant Molecular Biology, v.50, n.1, p.361-389, 1999.

HARRISON, M.J.; DIXON, R.A. Isoflavonoid accumulation and expression of defense gene transcripts during the establishment of vesicular-arbuscular mycorrhizal associations in roots of Medicago truncatula. Molecular plant microbe interactions, v.6, n.5, p.643-645, 1993.

HARRISON, M.J.; DIXON, R.A. Spatial patterns of expression of flavonoid/ isoflavonoid phatway genes during the interactions between roots of Medicago truncatula and the mycorrhizal fungus Glomus versiforme. Plant Journal, v.6, n.1, p.9-20, 1994.

HERNÁNDEZ-SEBASTIÁ, C.; SAMSON, G.; BERNIER, P.Y.; PICHÉ, Y.; DESJARDINS, Y. Glomus intraradices causes differential changes in amino acid and starch concentrations of in vitro strawberry subjected to water stress. New Phytologist, v.148, n.1, p. 177-186, 2000.

HINE, J.C.; SPRENT, J.I. Growth oh Phaseolus vulgaris on various nitrogen sources: the importance of urease. Journal of Experimental Botany, v.39, n.208, p.15051512, 1988.

HO, I.; TRAPPE, J.M. Nitrate-reducing capacity of two vesicular-arbuscular mycorrhizal fungi. Mycologia, v.67, n.4, p.886-888, 1975

HUTCHISON, L.J. Studies on the systematics of ectomycorrhizal fungi in acxenic culture. II. The enzimatic degradation of selected carbon and nitrogen compounds. Canadian Journal of Botany, v.68, n.7, p. 1522-1530, 1990.

ISMAIL, M.A.; ABDEL-SATER, M.A. Mycoflora inhabiting water closet environments. Mycoses, v.37, n.1-2, p.53-57, 1994. 
JOHANSEN, A.; FINLAY, R.D.; OLSSON, P.A. Nitrogen metabolism of external hiphae of the arbuscular mycorrhizal fungus Glomus intraradices. New Phytologist, v.133, n.4, p.705-712, 1996.

JOHANSEN, A.; JAKOBSEN, I.; JENSEN, E.S. External hyphae of vesiculararbuscular mycorrhizal fungi associated with Trifolium subterraneum L. III. Hiphal transport of ${ }^{32} \mathrm{P}$ and ${ }^{15} \mathrm{~N}$. New Phytologist, v.124, n.1, p.61-68, 1993.

JONGEN, M.; FAY, P.; JONES, M.B. Effects of elevated carbon dioxide and arbuscular mycorrhizal infection on Trifolium repens. New Phytologist, v.132, n.3, p. $413-423,1996$.

KALDORF, M., SCHMELZER, E.; BOTHE, H Expression of maize and fungal nitrate reductase genes in arbuscular mycorrhiza. Molecular plant microbe interactions, v.11, n.6, p.439-448, 1998.

KHALIQ, A. Effect of inoculation with vesicular-arbuscular mycorrhizal fungus (Glomus mosseae) and application of phosphorus on dry matter and phosphorus uptake of maize (Zea mays L.). Journal-of-Animal-and-Plant-Sciences (Pakistan), v. 7, n. 1-2, p. 45-48, 1997.

KHALIQ, A.; SANDERS, F.E. Effects of phosphorus application and vesicular arbuscular mycorrhizal inoculation on the growth and phosphorus nutrition of maize. Journal-of-plant-nutrition (USA), v. 20, n.11, p. 1607-1616, 1997.

KIM, K.Y.; YANG, C.H.; LEE, M.H. Expression of the recombinant Klebsiella aerogenes UreF protein as a MalE fusion. Archives in pharmacology research, v.22, n.3, p.274-278, 1999.

LAMBAIS, M.R.; MEHDY, M.C. Soybean roots infected by Glomus intraradices stains differing in infectivity exhibit differential chitinase and beta-1,3-glucanase expression. New Phytologist, v.134, n.3, p.531-538, 1996.

LAMBAIS, M.R.; MEHDY, M.C. Supression of endochitinase, $\beta$-1,3-endoglucanase, and chalcone isomerase expression in bean vesicular-arbuscular mycorrhizal roots under different soil phosphate conditions. Molecular Plant-Microbe Interactions, v.6, n.1, p.75-83, 1993. 
LAMBAIS, M.R. Aspectos bioquímicos e moleculares da relação fungo-planta em micorrizas arbusculares. In: SIQUEIRA, J.O. (Ed.) Avanos em fundamentos e aplicações de micorrizas. Lavras: UFLA/DCS e DCF, 1996. p.5-38.

LEA, P.J.; BLACKWELL, D.; CHEN, F.; et al. Enzimes of ammonia assimilation. In: LEA, P.J. (ed) Methods in plant biochistry, vol3. London: Academic Press, 1990. p.257-276.

LEE, M.H.; MULROONEY, S.B.; RENNER, M.J.; MARKOWICZ, Y.; HAUSINGER, R.P. Klebsiella aerogenes urease gene cluster: sequence of ure $D$, and demonstration that four accessory genes (ureD, ureE, ureF and ureG) are involved in nickel metallocenter biosynthesis. Journal of Bacteriology, v. 174, n.13, p.43244330, 1992.

LYND, J.Q.; ANSMAN, T.R. Lichen mycobionts of mycorrhizalsymbiosis with nitrogen-fixation of Showy Partridge Pea. Journal of Plant Nutrition, v.17, n.2-3, p.445-459, 1994.

MACKAY, E.M; PATEMAN, J.A. The regulation of urease activity in Aspergillus nidulans. Biochemical Genetics, v.20, n.7-8, p.763-776, 1982.

MALAVOLTA, E.; VITTI, G.C.; OLIVEIRA, S.A. Metodologia para análise de elementos em material vegetal. In: MALAVOLTA, E.; VITTI, G.C.; OLIVEIRA, S.A. Avaliação do estado nutricional das plantas: princípios e aplicações. Piracicaba: Associação Brasileira para Pesquisa da Potassa e do Fosfato, 1997. p.231-308.

MCGEE, D.J.; MAY, C.A.; GARNER, R.M.; HIMPSI, J.M.; MOBELY, H.I.T. Isolation of Helicobacter pylori genes that modulate urease activity. Journal of Bacteriology, v.181, n.8, p.2477-2484, 1999

MIFLIN, B.J.; LEA, P.J. Pathway of nitrogen assimilation in plants. Phytochemistry, v. 15, n. 6, p. 873-885, 1976.

MIKSCH, G.; ARNOLD, W.; LENTZSCH, P.; PRIEFER, U.B.; PÜHLER, A. A 4.5kb DNA region of Rhizobium meliloti involved in determining urease and hidrogenase activities carries the structural genes for urease (ure $A, u r e B$, ureC) interrupted by 
other open reading frames. Molecular General Genetics, v.242, n.5, p.539-550, 1994.

MOBLEY, H.L.T.; HAUSINGER, R.P. Microbial ureases: significance, regulation, and molecular characterization. Microbial Reviews, v.53, n.1, p.85-108, 1989.

MONZ CA, HUNT HW, REEVES FB, et al. The response of mycorrhizal colonization to elevated co2 and climate-change in Pascopyrum-smithii and Bouteloua-gracilis. Plant soil, v.165, n.1, p.75-80, 1994.

MULROONEY, S.B.; HAUSINGER, R.P. Sequence of the Klebsiella aerogenes urease genes and evidence for acessory proteins facilitating nickel incorporation. Journal of Bacteriology, v.172, n. 10, p.5837-5843, 1990.

NAGAHASHI, G.; DOUDS, D.D. Apressorium formation by Am fungi on isolated cell walls of carrot roots. New Phytologist, v.136, n.2, p.299-304, 1997.

NOGUEIRA, A.V. As micorrizas e o excesso de metais. In: SIQUEIRA, J.O. (Ed.) Avanos em fundamentos e aplicações de micorrizas. Lavras: UFLA/DCS e DCF, 1996. p. 135-174.

OLIVER, A.J.; SMITH, S.E.; NICHOLAS, D.J.D.; et al. Activity Of Nitrate Reductase In Trifolium-Subterraneum - Effects Of Mycorrhizal Infection And Phosphate Nutrition. New Phytologist, v.94, n.1, p 63-79, 1983.

PACOVSKY, R. S. Carbohidrate, protein and amino acid status of Glycine-GlomusBradyrhizobium symbioses. Physiologia plantarum, v. 75, n.3, p.346-354, 1989.

PEREIRA, E.G.; SIQUEIRA, J.O; DOVALE, F.R.; et al. Influência do nitrogênio mineral no crescimento e colonização micorrízica de mudas de árvores. Pesquisa Agropecuária Brasileira, v.31, n.9, p.653-662, 1996.

PETRUCCIOLI, M.; FEDERICI, R.G. A note on the producion of extracelular hydrolitic enzymes by yeast-like fungi and related microorganisms. Annali di Microbiologia ed Enzimologia, v.42, n.1, p.81-86, 1992.

PHILLIPS, J.M.; HAYMAN, D.S. Improved procedures for clearing roots, and staining parasitic and vesicular-arbuscular mycorrhizal fungi for rapid assessment of infection. Transactions of British Mycological Society, v.55, n.1, p.158-162, 1970. 
RÍOS-RUIZ, W.F. Atividades de superóxido dismutase, catalases e peroxidase durante o desenvolvimento de micorrizas arbusculares em feijoeiro, sob condições de baixo e alto nível de fosfato. Piracicaba, 1998. Dissertação (Mestrado) - Escola Superior de Agricultura "Luiz de Queiroz", Universidade de São Paulo.

RUIZ-LOZANO, J.M.; ROUSSEL, H; GIANINAZZI, S; et al. Defense genes are differentially induced by a mycorrhizal fungus and Rhizobium $\mathrm{sp}$. in wild-type and symbiosis-defective pea genotypes. Molecular Plant Microbe Interactions, v.12, n.11, p.976-984, 1999.

SALZER, P.; BONANOMI, A.; BEYER, K; et al. Differential expression of eight chitinase genes in Medicago truncatula roots during mycorrhiza formation, nodulation, and pathogen infection. Molecular Plant Microbe Interactions, v.13, n.7, p.763-777, 2000.

SANDERS, I.R.; STREITWOLF-ENGEL, R.; VAN DER HEIJDEN, M.G.A.; et al. Increase allocation to external hyphae of arbuscular mycorrhizal fungi under $\mathrm{CO}_{2}$ enrichment. Oecologia, v.117, n.4, p.496-503, 1998.

SANDERS, I.R.; CLAPP, J.P., WIEMKEN, A. The genetic diversity of arbuscullar mycorrhizal fungi in natural ecosystems - a key to understanding the ecology and functioning of the mycorrhizal symbiosis. New Phytologist, v.133, n.1, p.123-134, 1996.

SARRUGE, J.R. Soluções nutritivas. Summa Phytopatológica, v.1, n.3, p.231-233, 1975.

SCHELLENBAUM, L.; MÜLLER, J.; BOLLER, T.; WIEMKEN, A.; SCHÜEPP,H. Effects of drought on non-mycorrhizal and mycorrhizal maize: changes in the pools of non-structural carbohydrates, in the activities of invertase and trehalase, and in the pools of amino acids and imino acids. New Phytologist, v.138, n.1, p.59-66, 1998.

SHIRTLIFFE, S.J.; VESSEY, J.K. A nodulation (Nod ${ }^{+} /$Fix ${ }^{-}$) mutante of Phaseolus vulgaris $\mathrm{L}$. has nodule-like strutures lacking peripheral vascular bundles ( $\left.\mathrm{Pvb}^{-}\right)$and is resistent to mycorrhizal infection (Myc). Plant Science, v. 118, n.2, p.209-220, 1996. 
SILVEIRA, A.P.D. Micorrizas In: CARDOSO, E.J.B.N.; TSAI, S.M.; NEVES, M.C.P. Microbiologia do Solo. Campinas: Sociedade Brasileira de Ciência do Solo, 1992. p.257-283.

SIQUEIRA, J.O; POUYÚ, E; MOREIRA, F.M.S. Micorrizas arbusculares no crescimento pós-transplantio de mudas de árvores em solo com excesso de metais pesados. Revista Brasileira de Ciência do Solo, v.23, p.569-580, 1999.

SIRKO; A.; BRODZIK, R. Plant ureases: roles and regultion. Acta Biochimica Polonica, v.47, n.4, p.1189-1195, 2000.

SKOKUT, T.; FILNER, P. Slow adaptative changes in urease levels of tobacco cells cultured on urea and other nitrogen sources. Plant Physiology, v.65, n.5, p. 995$1003,1980$.

SMITH, S.E.; GIANINAZZI-PEARSON, V. Physiological interactions between symbionts in vesicular-arbuscular mycorrhizal plants. Annual Reviews of Plant Physiology and Plant Molecular Biology, v.32, n.1, p.221-244, 1988.

SMITH, G.S.; CORNFORTH, I.S.; HENDERSON, H.V. Critical Leaf Concentrations For Deficiencies Of Nitrogen, Potassium, Phosphorus, Sulfur, And Magnesium In Perennial Ryegrass. New Phytologist, v.101, n.3, p.393-409, 1985.

SMITH; S.E.; READ, D.J. eds. Mycorrhizal Symbiosis. San Diego, CA: Academic, 1997.

SPANU, P.; BOLLER, T.; LUDWIG, A.; et al. Chitinase in roots of mycorrhizal allium-porrum - regulation and localization. Planta, v.177, n.4, p.447-55,1989.

SPANU, P.; BONFANTE-FASOLO, P. Cell-wall-bound peroxidase activity in roots of mycorrhizal Allium porrum. New Phytologist, v.109, n.1, p.119-124, 1988.

STADDON, P.L.; FITTER, A.H. Does elevated atmospheric carbon dioxide affect arbuscular mycorrhizas? Trends in Ecology and Evolution, v.13, n.11, p.455-458, 1998.

SUBRAMANIAN, K.S.; CHAREST, C. Arbuscular mycorrhizae and nitrogen assimilation in maize after drought and recovery. Physiologia plantarum, v.102, n.2, p.285-296, 1998. 
TAN, X.W.; YKEDA, H.; ODA, M. The absorption, trnaslocation, and assimilation of urea nitrate or ammonium in tomato plants at different plant growth stages in hidroponic culture. Scientia horticulturae, v.84, n.2, p.275-283, 2000.

TESTER, M.; SMITH, S.E.; SMITH, F.A. The phenomenon of "nonmycorrhizal" plants. Canadian Journal of Botany, v.65, n.3, p.419-431, 1987.

TOMAS, R.J.; SCHRADER, L.E. Ureid metabolism in higher plants. Phytochemistry, v.20, n.1, p.361-371, 1981.

TORISKY, R.S.; GRIFFIN, J.D.; YENOFSKY, R.L.; POLACCO, J.C. A single gene (Eu4) encodes the tissue-ubiquitous urease of soybean. Molecular General Genetics, v.242, n.4, p. 404-414, 1994.

VIERHEILIG, H.; ALT, M.; NEUHAUS, J.M..; et al. Colonization of transgenic Nicotiana silvestys plants, expressing different forms of Nicotiana tabaccum chitinase, by the root pathogen Rhizoctonia solani and by the mycorrhizal fungus Glomus mosseae. Molecular Plant-Microbe Interactions, v.6, n.2, p.261-264, 1993.

VIERHEILIG, H.; ALT, M.; LANGE, J.; et al. Colonization of transgenic tobacco constitutively expressing pathogenesis-related proteins by the vesicular-arbuscular mycorrhizal fungus Glomus mosseae. Applied and Environmental Microbiology, v.61, n.8, p.3031-3034, 1995.

VOLPIN, H. PHILLIPS, D.A., OKON, Y., KAPULNIK, Y. Supression of an isoflavonoid phytoalexin defense response in mycorrhizal alfafa roots. Plant Physiology, v.108, n.4, p.1449-1454, 1995.

VOLPIN, H., ELKIND, Y., OKON, Y., KAPULNIK, Y. A vesicular arbuscular mycorrhizal fungus (Glomus intraradix) induces a defense response in alfafa roots. Plant Physiology, v.104, n.2, p.683-689, 1994.

WITTE, C.P.; ISIDORE, E.; TILLER, S.A.; et al. Functional characterization of urease acessory protein G (ureG) from potato. Plant molecular biology, v.45, n.2, p.169$179,2001$.

WRIGTH S.F.; FRANKE-SNYDER, M.; MORTON, J.B., UPADHYAYA, A. Timecourse study and partial characterization of a protein on hyphae os arbuscular 
mycorrhizal fungi during active colonization of roots. Plant and Soil, v.181, n.2, p.193-203, 1996.

WRIGHT, S.F.; UPADHYAYA, A. Extraction of an abundant and unusual protein from soil and comparasion with hyphal protein of arbuscular mycorrhizal fungi. Soil Science, v.161, n.3, p.575-586, 1996.

WYSS, P., BOLLER, T., WIEMKER, A. Phytoalexin response is elicited by a pathogen (Rhizoctonia solani) but not by a mycorrhizal fungus (Glomus mosseae) in soybean roots. Experientia, v.47, n.4, p.395-399, 1991. 